Discussion Paper No. 09-072
Intensifying the Use of Benefit Sanctions -
An Effective Tool to Shorten Welfare
Receipt and Speed up Transitions
to Employment?
Bernhard Boockmann, Stephan L. Thomsen,
and Thomas Walter

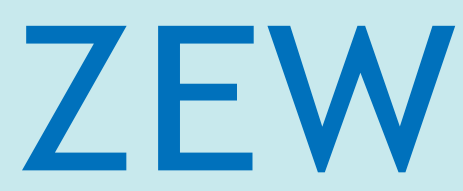

Zentrum für Europäische Wirtschaftsforschung $\mathrm{GmbH}$ Centre for European Economic Research 
Discussion Paper No. 09-072

\title{
Intensifying the Use of Benefit Sanctions - An Effective Tool to Shorten Welfare Receipt and Speed up Transitions to Employment?
}

\author{
Bernhard Boockmann, Stephan L. Thomsen, \\ and Thomas Walter
}

Download this ZEW Discussion Paper from our ftp server:

ftp://ftp.zew.de/pub/zew-docs/dp/dp09072.pdf

Die Discussion Papers dienen einer möglichst schnellen Verbreitung von neueren Forschungsarbeiten des ZEW. Die Beiträge liegen in alleiniger Verantwortung der Autoren und stellen nicht notwendigerweise die Meinung des ZEW dar.

Discussion Papers are intended to make results of ZEW research promptly available to other economists in order to encourage discussion and suggestions for revisions. The authors are solely responsible for the contents which do not necessarily represent the opinion of the ZEW. 


\section{Non-technical Summary}

During the last two decades many countries have reformed their welfare systems with the aim of shifting labor market policies from passive benefit receipt towards increased job search and work requirements. As part of this shift benefit sanctions are increasingly being used in the activation process when welfare recipients fail to comply with their duties. Benefit sanctions are a partial or complete reduction of the benefit level for a certain period of time. In Germany, sanctions have become much more commonplace after the reform of the welfare system in 2005 (the so-called 'Hartz IV' reform). Here, benefits are either cut by $10 \%$ or 30\% depending on the severeness of the infringement. In case of repeated infringements within one year sanctions can be augmented stepwise up to a total cut of $100 \%$.

Despite the increased use of benefit cuts, the empirical literature on the effect of sanctions on the transition from welfare to work is still limited and does not provide clear policy recommendations. A major drawback of existing studies is that they mostly have to rely on limited individual information or are restricted to small geographic areas. Generalizing these findings to welfare recipients in other regions or countries is not straightforward and requires strong assumptions. In addition, relying on individual information only is questionable. It ignores the fact that the imposition of sanctions not only depends on the characteristics of a welfare recipient but also on the characteristics of the welfare agency at which the individual is registered and which is in charge of the decision whether or not a sanction is applied. Benefit sanctions are not imposed uniformly when the individual does not comply with his or her duties. Rather, there is substantial discretion at the agency level. Some agencies are quite reluctant with respect to using sanctions while others apply sanctions more frequently.

Based on a unique data set, which combines individual information about welfare recipients with agency information, we use differences in sanction strategies and rates across welfare agencies to estimate the effect of a sanction on the drop-out from welfare and the uptake of employment. Precisely, we estimate the sanction effect for those individuals who are not sanctioned in an agency with a moderate sanction regime, but who will be sanctioned if the agency decides to change its policy and impose sanctions more frequently. This effect provides an estimate of the effectiveness of an intensified use of sanctions. Our results show that an intensified use of sanctions would be quite effective in reducing welfare dependency and enhancing employment uptake. A sanction increases the probability of leaving the welfare system within eight months after the benefit cut by about 70 percentage points. Similarly, the probability of taking up employment subject to social insurance contribution rises by more than 50 percentage points. Therefore, we have to conclude that a more intensive use of benefit cuts in accordance with the legal requirements would contribute to making the labor market activation of welfare recipients more effective and would substantially increase the transition rate from welfare to work. 


\section{Das Wichtigste in Kürze}

Mit der Umsetzung der sogenannten Hartz IV-Reform im Januar 2005 hat sich in Deutschland ähnlich wie in anderen Ländern Europas und Nordamerikas ein Paradigmenwechsel in der Arbeitsmarktpolitik vollzogen. Anstatt Hilfebedürftige primär ausschließlich monetär abzusichern, wird seither die Eigenverantwortung dieser Personen stärker betont und die Integration in den Arbeitsmarkt gefördert und gefordert. Zur Erreichung der Ziele werden vermehrt Sanktionen eingesetzt, wenn die Hilfebedürftigen ihren Pflichten während des Aktivierungsprozesses nur unzureichend nachkommen. Sanktionen sind Kürzungen der monetären Leistungen. In Deutschland dauern sie drei Monate an und betragen je nach Schweregrad der Pflichtverletzung entweder $10 \%$ oder $30 \%$. Bei wiederholten Pflichtverletzungen innerhalb eines Jahres können die Sanktionen schrittweise auf bis zu 100\% erhöht werden. Trotz einer zunehmenden Anzahl an empirischen Untersuchungen für verschiedene Länder ist der Kenntnisstand über die Wirkung von Sanktionen auf den Abgang aus dem Leistungsbezug und die Aufnahme von Beschäftigung noch gering; die Ableitung belastbarer arbeitsmarktpolitischer Handlungsempfehlungen ist daher schwierig.

Die wesentlichen Defizite der bisherigen Studien sind zum einen die beschränkte Aussagekraft der verwendeten Datensätze, zum anderen inadäquate Schätzverfahren zur Identifikation der interessierenden Wirkungen. Besonders zu kritisieren sind hierbei Ansätze, die lediglich auf individuelle Merkmale der Ersatzleistungsbezieher abstellen. Sie ignorieren die Tatsache, dass die Verhängung einer Sanktion nicht nur von den Charakteristika eines Hilfebedürftigen abhängt, sondern auch von den Eigenschaften der Grundsicherungsstelle, bei der der Hilfebedürftige registriert ist und die letztlich entscheidet, ob eine Sanktion ausgesprochen wird oder nicht. Sanktionen werden nicht automatisch verhängt, sobald ein Hilfebedürftiger eine Pflichtverletzung begeht. Vielmehr hat die Grundsicherungsstelle erheblichen Entscheidungsspielraum und kann selbständig und unabhängig über den Vollzug einer Leistungskürzung befinden. Dabei sind einige Grundsicherungsstellen eher zurückhaltend im Umgang mit Leistungskürzungen und sanktionieren kaum, während andere Grundsicherungsstellen Sanktionen häufig einsetzen.

Diese Unterschiede in den Sanktionsstrategien und -raten zwischen den Grundsicherungsstellen nutzen wir, um den Effekt einer Sanktion auf den Abgang aus dem Leistungsbezug und die Aufnahme von Beschäftigung zu bestimmen. Konkret berechnen wir den Sanktionseffekt für diejenigen Hilfebedürftigen, die in einer Grundsicherungsstelle mit moderater Sanktionspolitik nicht sanktioniert werden, aber eine Leistungskürzung hinnehmen müssten, wenn sich die Grundsicherungsstelle entscheiden würde, Sanktionen häufiger einzusetzen. Dieser Effekt beschreibt die Wirkung einer intensivierten Sanktionstätigkeit seitens der Grundsicherungsstellen. Unsere Ergebnisse zeigen, dass eine Intensivierung des Einsatzes von Sanktionen stark positive Effekte hat. Eine Leistungskürzung erhöht die Wahrscheinlichkeit, innerhalb von acht Monaten nach der Sanktion aus dem Leistungsbezug abzugehen, um etwa 70 Prozentpunkte. Ebenso steigt die Wahrscheinlichkeit, eine sozialversicherungspflichtige Beschäftigung zu finden, um mehr als 50 Prozentpunkte. Ein verstärkter Einsatz von Sanktionen im Rahmen der gesetzlichen Vorgaben würde somit zu einer effektiveren Aktivierung der Hilfebedürftigen beitragen und die Übergangsraten aus der Hilfebedürftigkeit hinaus in Beschäftigung deutlich erhöhen. 


\title{
Intensifying the Use of Benefit Sanctions - An Effective Tool to Shorten Welfare Receipt and Speed up Transitions to Employment?*
}

\author{
Bernhard Boockmann, IAW Tübingen $\&$ University of Mannheim $\mathscr{E}$ IZA \\ Stephan L. Thomsen $\ddagger$ University of Magdeburg \& ZEW Mannheim \\ Thomas Walter $\$$ ZEW Mannheim
}

This version: November 8, 2009

\begin{abstract}
Benefit sanctions imposed on non-compliant welfare recipients are a new element in the German welfare system. In practice, the sanction policy and the application of sanctions vary considerably across the 439 welfare agencies. Based on combined administrative and survey data, these differences are used as instrumental variables to estimate the effect of sanctions on the drop-out from welfare and the transition to employment. The estimated local average treatment effect (LATE) is an estimate of the effectiveness of an intensified use of sanctions. The results show that tightening sanction policy would be quite effective.
\end{abstract}

Keywords: benefit sanctions, welfare recipients, IV, LATE

JEL Classification: I38, J64, C31

${ }^{*}$ The authors wish to thank Veronica Amarante, Bernd Fitzenberger, Markus Frölich, Christina Gathmann, Olaf Hübler, and Jeff Smith for valuable comments. The paper has benefited from discussions at the Conference of the European Society for Population Economics in Seville 2009, the Conference of the Canadian Economic Association in Toronto, 2009, the Conference of the European Association of Labour Economists in Tallinn, 2009, the XXIV National Conference of Labour Economics (AIEL) in Sassari, 2009, the Workshop of the German Statistical Society in Merseburg, 2009, and the seminars at ZEW Mannheim and University of Michigan, 2009. The paper is part of the project Evaluation of the Experimentation Clause in $\S 6 c S G B$ II commissioned by the Federal Ministry of Labor and Social Affairs (BMAS). The data base for this study originated from a joint effort of ZEW Mannheim with IAB Nuremberg, TNS Emnid Bielefeld, and IAQ Gelsenkirchen to merge administrative and survey data to evaluate the effects of welfare assistance in Germany. Stephan Thomsen thanks the Stifterverband für die Deutsche Wissenschaft (Claussen-Simon-Stiftung) for financial support. The usual disclaimer applies.

${ }^{\dagger}$ Bernhard Boockmann is Director of Research at the Institute for Applied Economic Research (IAW), Tübingen. Address: Ob dem Himmelreich 1, D-72074 Tübingen, e-mail: bernhard.boockmann@iaw.edu, phone: (+49) 70719896 - 20, fax: (+49) 70719896 - 99

${ }^{\ddagger}$ Stephan L. Thomsen is Assistant Professor of Labor Economics at Otto-von-Guericke-University, Magdeburg, and Research Associate at the Centre for European Economic Research (ZEW), Mannheim. Address: PO Box 4120, D-39016 Magdeburg, e-mail: stephan.thomsen@ovgu.de, phone: +49 391 6718431, fax: +49 3916711700.

$\S$ Thomas Walter is Research Assistant at the Centre for European Economic Research (ZEW), Mannheim. Address: L7, 1, D-68161 Mannheim, e-mail: walter@zew.de, phone: +49621 1235363, fax: +49621 1235225. 


\section{Introduction}

Unemployment benefit sanctions are increasingly being used as part of the unemployment insurance and public welfare systems in many countries 1 Benefit payments are made conditional on requirements such as actively searching for a job or participation in active labor market programs. Sanctions (or the threat to impose them) are intended to provide incentives for the benefit recipients to comply with these requirements. In Germany, these elements have become much more commonplace after the reform of the German welfare system in 2005, which merged former social assistance and unemployment assistance into the new unemployment benefits II (UBII). The obligation to actively search for employment and to participate in welfare-to-work programs marks an important change in German welfare policy. For the first time, welfare recipients have become a target group of labor market activation. Benefit sanctions are now frequently imposed in the form of a partial or a complete revocation of benefits for a certain period of time ${ }^{2}$

The empirical literature on the effects of sanctions is still limited. Fredriksson and Holmlund (2006) provide a survey of theoretical and empirical research. A number of recent empirical studies have analyzed the ex-post effects of sanctions imposed on unemployment benefit recipients, e.g. Abbring, van den Berg, and van Ours (2005) for the Netherlands, Lalive, van Ours, and Zweimüller (2005) for Switzerland, Svarer (2007) for Denmark, or Müller and Steiner (2008) and Hofmann (2008) for Germany $3^{3}$ Some empirical evidence also exists for welfare recipients (see, e.g., van den Berg, van der Klaauw, and van Ours, 2004, for the Netherlands, Grogger and Karoly, 2005, or Blank and Haskins, 2001, for the US and Schneider, 2008, for Germany). Most of these studies establish positive effects on labor market outcomes. Thus, van den Berg, van der Klaauw, and van Ours (2004) find that the transition rate from welfare to work more than doubles after a benefit sanction has been imposed. Similarly, Müller and Steiner (2008) report positive effects of benefit sanctions on employment uptake for unemployed individuals in Germany. By contrast, Schneider (2008) analyzes the effects of benefit sanctions on the reservation wage for unemployment benefit II recipients and does not find a significant impact.

To date, the extant empirical literature does not yield clear policy recommendations. A major drawback is that these studies either rely on limited individual information or are restricted to small geographic areas. For example, Abbring, van den Berg, and van Ours (2005) use Dutch register data containing only a small number of individual characteristics. Therefore, they model

\footnotetext{
${ }^{1}$ Grubb (2000) provides an overview of a number of different unemployment insurance systems of selected OECD countries with a particular focus on benefit sanctions.

${ }^{2}$ Benefit sanctions have also been used for recipients of unemployment or social assistance before 2005, albeit far less intensely than UBII sanctions. See, e.g., Wilke (2004) for descriptive evidence on the use of sanctions for recipients of unemployment assistance.

${ }^{3}$ There may also be ex ante effects of sanctions due to the deterrence effect associated with the potential exposure to benefit sanctions. However, estimating ex ante effects on observable data is difficult since information on warnings is not usually available. One notable exception is provided by Lalive, van Ours, and Zweimüller (2005) who evaluate the effects of benefit sanctions on the unemployment duration. Their findings indicate that warnings (ex ante) and exposure (ex post) both have significant effects on labor market transitions.
} 
unobserved heterogeneity explicitly by using a multivariate mixed proportional hazards model to avoid potential selection bias in the estimates. The results of Lalive, van Ours, and Zweimüller (2005) are based on data for only three out of 26 Swiss cantons and van den Berg, van der Klaauw, and van Ours (2004) focus on welfare recipients in the Dutch city of Rotterdam only. Generalizing these findings to unemployment and welfare benefit recipients in other regions or countries is not straightforward and requires very strong assumptions.

Another limitation is the degree of sophistication in statistical analysis and the treatment effect chosen as the parameter of interest. For instance, while the more recent empirical studies for Germany are mostly based on comprehensive administrative data, the results are either purely descriptive (for example, Wilke, 2004) or affected by potential selection biases. Thus, Schneider (2008), Hofmann (2008), and Müller and Steiner (2008) use propensity score matching estimators to estimate average treatment effects on the treated (ATT) but ignore selection on unobservables. Estimation of the ATT is reasonable if the group intended to be sanctioned by the policy maker is actually exposed to benefit sanctions. However, identifying the intended group from observational data may be incomplete since sanctions are not imposed mechanically for certain infringements but depend on a number of factors. These factors comprise individual characteristics of the benefit recipients but also characteristics of the caseworker and the welfare agency administering the benefits. Moreover, although the probability of infringement may be systematically related to certain characteristics of the individual, addressing selectivity with respect to observed characteristics only is a questionable approach.

In practice, the likelihood of being sanctioned will not only depend on the observable and unobservable characteristics of the individual but also on the characteristics of the welfare agency at which an individual is registered and which is in charge of the actual imposition of sanctions. Benefit sanctions are not imposed uniformly when the individual does not comply with his or her duties during the activation process but there is substantial discretion at the agency level. As our data show, some agencies are quite reluctant with respect to using sanctions while others apply sanctions more frequently and even in cases of minor infringements. The role of the policy regime at the level of local agencies has so far been completely neglected in the empirical literature.

This paper aims to contribute to the literature in the following respects. Based on a unique new data set for Germany, we estimate the effects of benefit sanctions for UBII recipients in Germany on the transition to employment and the drop-out from welfare dependency. The data set combines information of a large survey of welfare benefits recipients with administrative information. The data were collected at 154 different welfare agencies across Germany. In addition to individual information, the data provide information on organizational aspects and strategies of the welfare agencies. In particular, we have access to survey information on the sanction strategy that is used in the respective welfare agency. Based on the different strategies of the welfare agencies, as well as on the frequency with which sanctions are actually imposed, 
we instrument the selection process at the individual level and estimate local average treatment effects (LATE, see Imbens and Angrist, 1994). Specifically, we estimate the effect of a sanction on individuals not sanctioned in an agency with a moderate sanction policy but sanctioned in an agency that imposes sanctions more frequently. Since the effect is estimated for those individuals who are not necessarily sanctioned because of a severe non-compliance but simply because the punishing agency regards sanctions as an important element of its activation and monitoring regime, the estimated LATE can be interpreted as a measure of the effectiveness of an intensified use of sanctions.

The remainder of this paper is organized as follows. Section 2 presents some details of the German welfare system and the institutional setting of benefit sanctions. The data used in the empirical analysis is described in section 3 . Our identification strategy of the effects of benefit sanctions on receiving welfare benefits and on employment is discussed in section 4. In section 5 we present the estimation results. The final section concludes.

\section{The German Welfare System and its Sanction Scheme}

The German welfare system was substantially reformed at the beginning of 2005 4 Before 2005, welfare recipients were eligible for social assistance (SA) if they had not contributed to unemployment insurance before. In addition, persons whose unemployment benefit (UB) claims had expired were eligible for unemployment assistance (UA). If UA was too low to provide a minimum living standard, a combination of UA and SA was granted. In contrast to UB, UA and SA were both means-tested. With the welfare reform of January 2005, both programs were replaced by the so-called unemployment benefits II scheme (UBII). In contrast to UA, which replaced up to $57 \%$ of the previous net earnings, UBII (as former SA) does not depend on former earnings. The means-test takes into account the wealth and income of all individuals living in the household. At the beginning of 2005, UBII cash payments amounted to EUR 345 in West Germany and to EUR 331 in East Germany. Meanwhile, the level of UBII in East Germany was adjusted to the Western level and UBII was slightly raised in both parts to compensate for inflation. In addition, UBII welfare payments also include compulsory social insurance contributions and costs of housing. Additional expenses for special needs may also be covered.

In order to be eligible for UBII, persons have to be aged between 15 and 64 years and be able to work for at least 15 hours per week. It is important to note that unemployment is not a prerequisite for receipt of UBII. Individuals who are employed but whose household income is

\footnotetext{
${ }^{4}$ This reform was the last part of a series of four major reforms of the German labor market which were enacted between 2003 and 2005. These reforms have become known as 'Hartz reforms' named after the chairman of the commission proposing the reforms. Since the reform of the welfare system is the last of the four reforms it is also referred to as the 'Hartz IV reform'. See Jacobi and Kluve (2007) for a description of all four 'Hartz reforms'.
} 
too low are also eligible for UBII. Claimants capable of work have to register with the local welfare agency and are obliged to participate in welfare-to-work programs. This obligation marks an important change in German welfare policy since for the first time welfare recipients are a target group of labor market activation. Before 2005, hardly any effort was made to reintegrate these persons into the labor market and welfare solely relied on passive benefit payments. Since 2005, the welfare recipients' rights and duties in the activation process are set out in a so-called 'integration contract' (Eingliederungsvereinbarung), an agreement between the welfare agency and the benefit recipient containing obligations with respect to program participation and job search activities, as well as detailing the services provided by the welfare agency. The integration contract is usually set up after the first meeting of a welfare recipient with the caseworker.

The caseworker counsels and advises the welfare recipient and decides about placement in welfare-to-work programs. If the caseworker detects non-compliance of the UBII recipient during the activation process, the welfare agency has the option of imposing a sanction by benefit revocation. Welfare recipients are informed about the possibility of sanctions in the integration contract and each time they are assigned to a program. Sanctions have a duration of three months and can be imposed for various reasons. For minor non-compliances, such as the failure to report to the welfare agency, benefits are cut by $10 \%$. 5 Mre severe infringements (lack of job search effort, refusal to accept a suitable job offer, refusal to participate in a program) lead to a benefit reduction of $30 \%$. In case of repeated incidents of severe infringements within one year, a second $(60 \%$ cut) or a third sanction $(100 \%$ cut) can be imposed $[6$ For UBII recipients below 25 years of age, benefits can be reduced by $100 \%$ even for the first incident of non-compliance.

\section{Data}

The empirical analysis is based on a unique data set that combines various different data sources. The core of these data is a two-wave panel survey of welfare recipients who received UBII in October 2006 or entered UBII receipt in the second half of 2006. These individuals were randomly sampled from the administrative records of the Federal Employment Agency. In the survey, two computer-assisted telephone interviews were conducted in the beginning of 2007 (January to April) and about one year later (November 2007 to March 2008). In the first wave, 24.563 interviews were realized, which form the basis for the analysis presented here.

The sample is stratified according to the following characteristics: age (15-24, 25-49, 50-64), children younger than three years living in the household and lone parent status. Furthermore, the sample is restricted to 154 out of 439 German welfare agencies. In each of these agencies,

\footnotetext{
${ }^{5}$ The basis for the sanction is the standard UBII.

${ }^{6} \mathrm{~A}$ similar possibility exists in the case of minor non-compliances where sanctions can be increased stepwise by $10 \%$ up to a cut of $100 \%$.
} 
between 100 and 300 interviews were conducted. The 154 agencies are chosen partly as a random selection of agencies, partly as nearest neighbors of those agencies randomly selected (see IAW and ZEW (2006)). Our results relate to those individuals who are registered at one of these agencies. See Figure A.1 in the appendix for an illustration of the sampled agencies. In our estimation approach we use sample weights to account for stratification. For more details on the realization of the survey, see ZEW, IAQ, and TNS Emnid (2008).

The survey includes individual characteristics (e.g. gender, age, marital and parent status, education, health and disability status, migration background), information on other household members (number, age and relation to the respondent) and details concerning the labor market status and history (current labor market state, former spells of insured and minor employment, former spells of unemployment, UBII receipt, participation in activation programs). Moreover, it contains information about basic skills (e.g. reading, writing, math and computer skills), further qualifications (e.g. driver's license), job search activities and information about benefit sanctions.

Importantly, respondents were asked whether they have ever been sanctioned by their welfare agency, and, if so, in which month the last sanction was imposed. We use this information to construct our treatment variable. We define those individuals as treated who report having been sanctioned for the first time and only once between October 2006 and April 2007. Since we focus on the effect of the first sanction imposed, persons with more than one sanction are deleted from the estimation sample, as earlier sanctions may have been imposed before October 2006. Individuals who explicitly state that they have been sanctioned before the sampling date are dropped from the data for the same reason. Since we do not have precise information on the amount of the benefit cuts, we are not able to distinguish between different levels of sanctions, and thus use the information as a binary indicator only. In addition, we impose two further restrictions on the estimation sample. Since the transition to employment is one of our two outcome variables of interest, we only look at individuals aged 18 to 57, who were unemployed at the beginning of their respective UBII spell. Individuals aged 58 or above can opt for the so-called relieved benefit entitlement. Within this scheme they are no longer required to actively search for employment, but remain on welfare benefits until retirement age. Individuals aged 15 to 17 are subject to compulsory schooling and cannot be expected to take up employment. Due to these restrictions, our sample size reduces to 15.361 observations.7

To provide the outcome variables of interest (departure from welfare receipt and transition to employment), administrative data from the Federal Employment Agency are merged to the survey data. These administrative data contain labor market states on a monthly basis for each individual up to December 2007, thus allowing us to follow each sanctioned person for at

\footnotetext{
${ }^{7}$ In detail, we drop 845 individuals aged 15 to $17,2.116$ persons aged 58 to 64 and 3.771 welfare recipients who are employed. Moreover, we exclude 811 persons with more than one sanction, 989 individuals with a sanction before the sampling date, 181 welfare recipients with a sanction in a former UBII spell and 489 observations with missing information.
} 
least eight months after the imposition of the sanction. For instance, for a person sanctioned in January 2007 we examine the labor market states from February to September 2007, and for a person sanctioned in April 2007 we use information on the period from May to December 2007. In order to compare the sanctioned individuals with the control group, we construct a hypothetical sanction date for the non-sanctioned group by drawing randomly from a uniform distribution of sanction dates from the period of October 2006 to April 2007 for each individual, i.e. the probability of receiving a (hypothetical) sanction in each of these months is assumed to be $1 / 7$. Given this (hypothetical) sanction date, the non-sanctioned group is also followed for eight months 87 The economic conditions during this observation period were quite favorable. In 2006 German GDP grew by $2.9 \%$ and in 2007 by $2.5 \%$. However, while the number of UB recipients decreased strongly in 2007 (yearly average of 1.253 million UB recipients in 2007 compared to 1.664 million in 2006), there was almost no decline in the number of welfare recipients (5.277 million in 2007 compared to 5.392 million in 2006).9

The combined administrative and survey data were linked to additional data at the agency level collected via surveys and case studies in all 154 sampled agencies in 2006 and 2007. They include variables that characterize the welfare agencies' organizational structure (e.g. type of case management, counseling concept, placement approach, mix of active labor market policies, number and qualification of caseworkers). Furthermore, regional information is added reflecting labor market conditions (e.g. share of unemployed persons, share of welfare recipients, GDP per worker).

\section{Estimation Approach}

To estimate the effect of a sanction on employment and the drop-out from welfare receipt, consider the linear probability model

$$
Y_{i}=X_{i} \beta+S_{i} \theta+u_{i}
$$

where $Y_{i}$ is the binary outcome variable of interest (for example, $Y_{i}=1$ denotes employment of individual $i$ and $Y_{i}=0$ denotes non-employment), $X_{i}$ is a vector of covariates (at individual and regional/agency level) and $S_{i}$ is a dummy variable indicating whether individual $i$ has been sanctioned $\left(S_{i}=1\right)$ or not $\left(S_{i}=0\right)$. Under the additional assumption that the error term $u_{i}$ has zero mean conditional on all covariates $X_{i}$ and $S_{i}$, one could apply simple OLS estimation to identify the effects of the right-hand side variables on $Y_{i}$. However, we cannot

\footnotetext{
${ }^{8}$ In some cases welfare recipients appeal against the imposition of a sanction. Social courts then have to decide on the legitimacy of the sanction. The average duration of litigations in these instances was 13.7 months in 2007 (see Statistisches Bundesamt (2009)). This period is considerably longer than our observation period of eight months. Therefore, we do not expect that a potential appeal of sanctioned survey participant against the benefit cut affects his or her behavior in our observation window. Since the sanction is in force despite the appeal, there is the same incentive to increase job search effort as in the case without an appeal.

${ }^{9}$ Figures according to the Federal Statistical Office (www.destatis.de) and the Federal Employment Agency (www.arbeitsagentur.de).
} 
rule out that $S_{i}$ is endogenous in our case, i.e. it may be that $\operatorname{Cov}\left(S_{i}, u_{i}\right) \neq 0$. In this case an OLS estimate of the sanction effect on $Y_{i}$ would be biased. Endogeneity of $S_{i}$ could be due to different reasons. For example, there could be a negative selection process driven by motivation or other unobservable factors such that individuals with unfavorable characteristics are sanctioned with higher probability. As a result, the OLS estimate of the effect of $S_{i}$ on $Y_{i}$ would be underestimated. However, there could also be a positive selection process initiated by caseworkers if those with unfavorable characteristics are not activated and thus not sanctioned. A positive selection of this kind would result in an overestimated effect of $S_{i}$ on $Y_{i}$. Hence, the bias of a simple OLS estimation is undetermined ex-ante.

To overcome the potential endogeneity of $S_{i}$ we use an instrumental variable approach to estimate the sanction effect on the outcome variable $Y_{i}$. Specifically, we consider a binary instrument $Z$ such that the first stage equation of a two-stage least squares estimator can be written as

$$
S_{i}=Z_{i} \delta+X_{i} \alpha+\epsilon_{i}
$$

where $X_{i}$ is the same vector of covariates as in equation (1) and $\epsilon_{i}$ is an error term with zero conditional mean. We allow this error term and the error term $u_{i}$ of equation (1) to be correlated across observations from the same agency. Under this specification the two-stage least squares estimator provides an estimate of $\theta$ in equation (1) that can be interpreted as a local average treatment effect (LATE, see Imbens and Angrist, 1994) 10 . It measures the impact of a benefit cut on those individuals who get a sanction when $Z$ changes its value from 0 to 1 .

As an instrument $Z$ we use two different variables: the sanction strategy of welfare agencies as reported by the agency managers (denoted as $Z_{1}$ ) and, alternatively, the actually observed sanction rate within the agencies (denoted as $Z_{2}$ ).

Welfare agencies play a crucial role for the use of sanctions since they have substantial discretion. Whether or not a sanction is actually imposed depends not only on the detected infringement but also on the general sanction policy of the welfare agency. Some agencies have a high affinity for sanctions whereas other agencies are more reserved. In the surveys and case studies at agency level described in section 3, agency managers were asked about the use and importance of sanctions within their agencies. The answers of managers were classified as depicted in Table

\section{1.}

The distribution of answers makes clear that benefit sanctions are valued differently across welfare agencies. While some agencies use sanctions only to comply with legal requirements, other agencies either apply sanctions more frequently, perhaps even when minor non-compliances of clients are detected, or less frequently, so that not all infringements are punished. The agency

\footnotetext{
${ }^{10}$ Alternatively, instead of a two-stage least squares estimator we could also use a bivariate probit model to estimate $\theta$ taking into account the binary nature of $Y_{i}$ and $S_{i}$ (see, e.g. Evans and Schwab, 1995). Both methods rely on different assumptions but yield similar results.
} 
Table 1: The use of sanctions in welfare agencies (number of agencies in brackets)
a) Sanctions are part of the activation strategy and applied frequently
b) Sanctions are supported but are not part of the activation strategy
c) Sanctions are used to comply with legal requirements
d) Sanctions are regarded sceptically, but nevertheless are used
e) Sanctions have no special role (neither positively nor negatively)
f) Sanctions are rarely used
g) Sanctions are used for general monitoring purposes, but are not re- garded as useful in single cases

will therefore have an impact on the individual probability of being sanctioned 11 Option a) of Table 1 differentiates between agencies that strategically impose sanctions with high incidence as opposed to agencies that do not. We use this differentiation to specify our first instrument $Z_{1}$, which has value one if an individual is registered at an agency that frequently imposes sanctions as part of its activation strategy and which is zero otherwise, i.e. if the welfare agency is classified as one of the options b) to g) of Table 1 . Using $Z_{1}$ as an instrument, the estimate of $\theta$ depicts the LATE of a sanction on those individuals who are sanctioned in an agency that frequently imposes sanctions and who would not be sanctioned in another (more reserved) agency. Thus, this LATE can be interpreted as an estimate of a more intensive use of sanctions.

For our alternative instrument $Z_{2}$ we make use of the actually observed sanction rates within the agencies. The sanction rate of an agency is defined to be the share of individuals registered at the respective agency who received a benefit cut between October 2006 and April 2007 ${ }^{12}$ To obtain a binary instrument, we differentiate between agencies with a sanction rate above the median $\left(Z_{2}=1\right)$ and agencies with a sanction rate below the median $\left(Z_{2}=0\right)$. Under this specification we estimate the LATE of a sanction on those individuals who would be sanctioned if the agency decided to increase the sanction rate from below to above the median level. Again, this effect can be interpreted as an estimate of a more intensive use of sanctions.

No matter which instrument $Z$ is used, the identification of a LATE depends on three conditions:

1) $Z$ is a valid instrument, i.e. $\operatorname{Cov}\left(Z_{i}, u_{i}\right)=0$ and $Z_{i}$ is partially correlated with $S_{i}$ once it is controlled for $X_{i} 13$

\footnotetext{
${ }^{11}$ An important instrument for the agencies' management in implementing a strategy are local guidelines (verhaltenslenkende Weisungen) for caseworkers. These guidelines are issued to control caseworker behavior in general. Specifically, in some agencies they may be used in order to induce caseworkers to impose sanctions frequently. Other welfare agencies might follow a milder sanction policy and refrain from encouraging or even discourage caseworkers from imposing sanctions. Therefore, the sanction strategy influences caseworkers' actions and, consequently, creates variation in the use of sanctions across welfare agencies.

${ }^{12}$ Both instruments $Z_{1}$ and $Z_{2}$ are highly correlated since the strategy of imposing sanctions frequently leads to a relatively high sanction rate within an agency, as will be shown in more detail in section 5

${ }^{13}$ In our specification we control for sex, age, schooling, migration background, household size, number of children, obstacles to employment, labor market status before welfare receipt, previous unemployment spells, regional information and the duration of the current welfare spell. The duration of the welfare spell is measured
} 
2) The probability of being sanctioned changes with the value of $Z$.

3) Individuals that are sanctioned in agencies of the type $Z=0$ must also be sanctioned in agencies of the type $Z=1$. And those individuals who are not sanctioned under $Z=1$ should not be sanctioned under $Z=0$ either (monotonicity assumption).

In the following, we verify these conditions referring to instrument $Z_{1}$, the sanction strategy of welfare agencies. A similar reasoning also applies for instrument $Z_{2}$. The monotonicity assumption is not testable, but it is very likely to hold in our case. If a sanction is imposed on an individual that is registered at an agency which rarely uses sanctions, the non-compliance must be severe and should also be detected and punished in an agency that sanctions frequently and cuts benefits even for minor infringements. Condition 2) is also satisfied. As will be shown in more detail in section 5, the sanction rate is indeed larger in agencies that frequently impose sanctions as part of their activation strategy. Therefore, the probability of an individual getting a sanction increases when $Z_{1}$ changes its value from zero to one. The partial correlation between $Z_{1}$ and $S_{i}$ as required in condition 1) also exists and will be discussed in more detail in the next section.

The final condition that has to be shown to hold is $\operatorname{Cov}\left(Z_{1}, u_{i}\right)=0$. This condition requires that $Z_{1}$ has no direct causal effect on $Y_{i}$. A direct effect would exist if individuals changed their behavior due to the actual realization of $Z_{1}$. This, however, is highly unlikely. The welfare agency's sanction strategy is not communicated to its clients. Hence, individuals do not know whether or not sanctions are used frequently in their agency. Therefore, they cannot draw comparisons with other agencies, whose strategies are even more difficult to find out. Thus, there should not be any behavioral response of individuals to the sanction strategy. If welfare recipients were aware of the sanction strategies of the agencies, the only way to avoid a tough sanction regime for a person registered at an agency that frequently imposes sanctions would be to move to another region, since individuals are forced to register with the agency at the place of residence. However, financial constraints are likely to prevent welfare recipients from moving. In addition, welfare agencies are quite reluctant to support a move since they would have to pay most of the costs.

It is also unlikely that the socio-demographic composition of the welfare recipients or the labor market situation drives an agency to adopt a certain sanction strategy. As can be seen from Figure A.2 in the appendix, agencies that sanction frequently and agencies that do not, appear to be distributed more or less randomly across the sampled regions. In many cases, agencies that sanction frequently and non-frequently directly border each other. In the city of Berlin five welfare agencies are sampled. Two of them use sanctions frequently whereas three do not.

as the number of months on benefits before the sampling date in October 2006. Due to the time span between sampling and interview date, not all individuals report a starting date of welfare receipt before October 2006. Some left and re-entered the welfare system during fall and winter 2006/2007 and thus report a starting date after October 2006. For these individuals the duration variable is set to 0 . An additional dummy variable takes these late starting dates into account. 
Since Berlin can be regarded as a single labor market, which is identical for all five agencies within the city, and since the composition of welfare recipients in these five agencies is quite similar, it is unlikely that the sanction strategy of an agency depends on the labor market state or the sociodemographic characteristics of the welfare recipients. A similar picture arises with respect to the actually observed sanction rates within the agencies (see Figure A.3). Given this (descriptive) evidence we conclude that both $Z_{1}$ and $Z_{2}$ satisfy all requirements to be valid instruments for the identification of the LATEs we want to estimate via equations (1) and (2). Our estimation results are presented in the next section.

\section{Empirical Analysis}

\subsection{Descriptive Evidence}

Before we present and discuss our estimation results, we provide descriptive statistics on the sanction strategy $\left(Z_{1}\right)$ and the actually observed sanction rates $\left(Z_{2}\right)$ in Table 2 .

Table 2: Sanction rates and number of observations

\begin{tabular}{llllll}
\hline \hline & \multicolumn{5}{c}{ Full sample } \\
\cline { 2 - 6 } & \multicolumn{5}{c}{$4.34 \%$} \\
\cline { 2 - 3 } & $Z_{1}=0$ & $Z_{1}=1$ & & $Z_{2}=0$ & $Z_{2}=1$ \\
\cline { 2 - 3 } \cline { 5 - 6 } & $4.01 \%$ & $5.75 \%$ & & $1.89 \%$ & $6.54 \%$ \\
\hline Sanctioned & 500 & 167 & & 137 & 530 \\
Non-sanctioned & 11957 & 2737 & & 7121 & 7573 \\
Total observations & & \multicolumn{3}{c}{15361} \\
\hline \hline
\end{tabular}

Remarks: $Z_{1}$ refers to the sanction strategy of welfare agencies. $Z_{1}=0$ denotes less strict agencies and $Z_{1}=1$ denotes frequently sanctioning agencies. $Z_{2}$ refers to the actually observed sanction rates within welfare agencies. $Z_{2}=0$ denotes agencies with a sanction rate below the median and $Z_{2}=1$ denotes agencies with a sanction rate above the median.

The agency strategy of applying sanctions frequently is indeed highly correlated with the imposition of sanctions as reported by the individuals in the survey. While in the full sample comprising all 154 welfare agencies $4.34 \%$ of the interviewees received a sanction between October 2006 and April 2007, the sanction rate is significantly larger for agencies that apply sanctions frequently as part of their activation strategy. Within these agencies the sanction rate amounts to $5.75 \%$, compared to $4.01 \%$ in the remaining agencies. This is a remarkable difference bearing in mind that the two variables considered are measured at different levels and that the sanction strategy varies at the agency level only. The difference is even larger when we look at the actually observed sanction rates. In agencies with a sanction rate above the median, $6.54 \%$ of welfare recipients received a sanction, while for the other agencies we observe a sanction rate of $1.89 \%$ only. Given these differences, both $Z_{1}$ and $Z_{2}$ fulfill the second requirement mentioned in section 4 to identify a LATE: The probability of being sanctioned changes with the value of 
the instrument. In the remaining part of the analysis we will mainly focus on $Z_{1}$ and use $Z_{2}$ to check the robustness of our results.

Table 3 presents descriptive statistics. We compare means of the variables used as covariates in the econometric analysis for sanctioned and for non-sanctioned individuals and for those individuals registered at agencies that frequently impose sanctions and for indivduals registered at all other agencies. In addition, $p$-values of $t$-tests on the equality of means are displayed to allow for a meaningful discussion of differences.

The left-hand side of Table 3 shows that male, younger, and less qualified individuals are most likely to have a benefit sanction imposed on them. Moreover, singles, and, to a lesser degree, individuals without children are relatively frequently subject to sanctions. Disabled persons and those with care obligations are less likely to receive a sanction. There also exist regional differences in sanction probabilities. In East Germany a smaller number of sanctions are imposed as compared to West Germany. In general, the better the labor market conditions, the more sanctions are imposed, as is reflected by the differences with respect to unemployment rates and the GDP (both measured one year before the welfare reform in December 2003). However, no significant differences in sanction probabilities exist with respect to the share of welfare recipients in a region 14

The middle part of Table 3 clearly shows that agencies with different sanction strategies are quite similar with respect to the composition of their clients. Only small differences are apparent concerning schooling achievement, household composition and migration status. Slightly more singles, persons without children, and persons with the lowest school leaving certificate (secondary general school) are registered at agencies that frequently impose sanctions than at the other agencies. Migrants are somewhat under-represented. More important differences exist with respect to regional characteristics. In rural areas, agencies seem to impose fewer sanctions than in urban districts. For East Germans, the probability of being registered at an agency with a tough sanction policy is a little higher than for West Germans. No clear picture arises with respect to the macroeconomic variables. While agencies that apply sanctions frequently are over-represented in regions with a high welfare-to-population ratio, almost no difference exists with respect to the unemployment rate. We do not detect any statistically significant difference with respect to GDP, either. Thus, the labor market state does not seem to determine the sanction strategy of an agency, as is required for a strategy in order to be a valid instrument. Nevertheless, the descriptive analysis makes it clear that one should control for regional variables when estimating the effect of benefit cuts. This is particularly important when using

\footnotetext{
${ }^{14}$ The welfare ratio is also measured in December 2003, but does not include former UA recipients and thus refers to former SA recipients only. All three macroeconomic variables (unemployment ratio, GDP and welfare ratio) have been collected for all 439 welfare agencies in Germany. Agencies that face an unemployment rate larger than the $75^{\text {th }}$ percentile of all unemployment rates across agencies are considered as agencies with a high unemployment rate and individuals registered at these agencies are classified respectively. The same procedure applies for GDP and the welfare ratio.
} 
instrument $Z_{2}$. As can be seen from the right-hand side of Table 3 , differences between agencies with $Z_{2}=0$ and $Z_{2}=1$ are somewhat larger than between agencies with $Z_{1}=0$ and $Z_{1}=1$.

Table 3: Descriptive statistics

\begin{tabular}{|c|c|c|c|c|c|c|c|c|c|}
\hline & $\mathrm{S}=0$ & $\mathrm{~S}=1$ & p-val. & $Z_{1}=0$ & $Z_{1}=1$ & p-val. & $Z_{2}=0$ & $Z_{2}=1$ & p-val. \\
\hline \multicolumn{10}{|l|}{ Gender } \\
\hline Male & 0.459 & 0.565 & 0.000 & 0.464 & 0.464 & 0.973 & 0.465 & 0.463 & 0.821 \\
\hline \multicolumn{10}{|l|}{ Age } \\
\hline $18-24$ & 0.203 & 0.381 & 0.000 & 0.210 & 0.217 & 0.422 & 0.209 & 0.213 & 0.469 \\
\hline $25-34$ & 0.207 & 0.258 & 0.002 & 0.209 & 0.208 & 0.863 & 0.205 & 0.213 & 0.264 \\
\hline $35-44$ & 0.211 & 0.174 & 0.023 & 0.209 & 0.207 & 0.798 & 0.210 & 0.208 & 0.726 \\
\hline $45-57$ & 0.379 & 0.187 & 0.000 & 0.371 & 0.368 & 0.751 & 0.376 & 0.366 & 0.208 \\
\hline \multicolumn{10}{|l|}{ Schooling } \\
\hline Secondary general school & 0.443 & 0.505 & 0.001 & 0.441 & 0.466 & 0.013 & 0.412 & 0.475 & 0.000 \\
\hline Intermediate secondary school & 0.338 & 0.262 & 0.000 & 0.338 & 0.319 & 0.045 & 0.376 & 0.297 & 0.000 \\
\hline University entrance diploma & 0.160 & 0.123 & 0.010 & 0.160 & 0.154 & 0.467 & 0.156 & 0.161 & 0.332 \\
\hline Other or missing & 0.059 & 0.109 & 0.000 & 0.061 & 0.061 & 0.939 & 0.056 & 0.066 & 0.006 \\
\hline \multicolumn{10}{|l|}{ Migration background } \\
\hline Migrant & 0.247 & 0.258 & 0.539 & 0.252 & 0.231 & 0.018 & 0.223 & 0.270 & 0.000 \\
\hline \multicolumn{10}{|l|}{ Household size } \\
\hline 1 person & 0.345 & 0.402 & 0.003 & 0.341 & 0.376 & 0.000 & 0.323 & 0.370 & 0.000 \\
\hline 2 persons & 0.278 & 0.229 & 0.006 & 0.280 & 0.257 & 0.011 & 0.295 & 0.258 & 0.000 \\
\hline 3 or more persons & 0.377 & 0.369 & 0.666 & 0.379 & 0.367 & 0.233 & 0.383 & 0.371 & 0.155 \\
\hline \multicolumn{10}{|l|}{ Number of children } \\
\hline No children & 0.611 & 0.651 & 0.040 & 0.609 & 0.629 & 0.040 & 0.610 & 0.615 & 0.548 \\
\hline 1 child & 0.214 & 0.201 & 0.425 & 0.216 & 0.203 & 0.140 & 0.223 & 0.205 & 0.006 \\
\hline 2 or more children & 0.175 & 0.148 & 0.075 & 0.176 & 0.167 & 0.293 & 0.167 & 0.180 & 0.030 \\
\hline \multicolumn{10}{|l|}{ Obstacles to employment } \\
\hline Disabled person & 0.105 & 0.054 & 0.000 & 0.103 & 0.101 & 0.766 & 0.098 & 0.106 & 0.119 \\
\hline Care obligation & 0.033 & 0.019 & 0.055 & 0.033 & 0.030 & 0.488 & 0.035 & 0.030 & 0.065 \\
\hline \multicolumn{10}{|c|}{ Status before receipt of welfare benefits } \\
\hline (Minor) employment & 0.322 & 0.396 & 0.000 & 0.326 & 0.325 & 0.943 & 0.319 & 0.331 & 0.109 \\
\hline \multicolumn{10}{|c|}{ Number of previous unemployment spells } \\
\hline 0 or 1 & 0.389 & 0.370 & 0.340 & 0.387 & 0.393 & 0.541 & 0.391 & 0.385 & 0.418 \\
\hline 2 or 3 & 0.370 & 0.379 & 0.624 & 0.373 & 0.358 & 0.130 & 0.364 & 0.376 & 0.150 \\
\hline 4 or more & 0.183 & 0.196 & 0.384 & 0.183 & 0.187 & 0.606 & 0.188 & 0.180 & 0.209 \\
\hline Missing & 0.058 & 0.054 & 0.644 & 0.057 & 0.062 & 0.317 & 0.056 & 0.059 & 0.428 \\
\hline \multicolumn{10}{|l|}{ Regional information } \\
\hline City district & 0.300 & 0.337 & 0.040 & 0.289 & 0.355 & 0.000 & 0.283 & 0.318 & 0.000 \\
\hline East Germany & 0.253 & 0.153 & 0.000 & 0.244 & 0.267 & 0.009 & 0.369 & 0.140 & 0.000 \\
\hline Unemployment ratio (high) & 0.255 & 0.160 & 0.000 & 0.247 & 0.263 & 0.074 & 0.366 & 0.147 & 0.000 \\
\hline GDP (high) & 0.286 & 0.361 & 0.000 & 0.291 & 0.280 & 0.216 & 0.209 & 0.360 & 0.000 \\
\hline Welfare ratio (high) & 0.284 & 0.289 & 0.779 & 0.276 & 0.323 & 0.000 & 0.281 & 0.287 & 0.404 \\
\hline \multicolumn{10}{|l|}{ Current welfare spell } \\
\hline Months in welfare before $10 / 2006$ & 12,437 & 10,927 & 0.000 & 12,356 & 12,440 & 0.660 & 12.806 & 11.982 & 0.000 \\
\hline Start after $10 / 2006$ or missing & 0.183 & 0.178 & 0.774 & 0.186 & 0.170 & 0.047 & 0.183 & 0.182 & 0.912 \\
\hline Observations & 14694 & 667 & 15361 & 12457 & 2904 & 15361 & 7258 & 8103 & 15361 \\
\hline
\end{tabular}

Remarks: $\mathrm{S}=0$ denotes non-sanctioned individuals and $\mathrm{S}=1$ denotes sanctioned individuals. $Z_{1}$ refers to the sanction strategy of welfare agencies. $Z_{1}=0$ denotes less strict agencies and $Z_{1}=1$ denotes frequently sanctioning agencies. $Z_{2}$ refers to the actually observed sanction rates within welfare agencies. $Z_{2}=0$ denotes welfare agencies with a sanction rate below the median and $Z_{2}=1$ denotes agencies with a sanction rate above the median. The p-values derive from t-tests on the equality of means of the displayed variables for $\mathrm{S}=0$ and $\mathrm{S}$ $=1$, for $Z_{1}=0$ and $Z_{1}=1$ and for $Z_{2}=0$ and $Z_{2}=1$, respectively.

Table 4 displays the means of our outcome variables. The columns contain mean rates of outflow from welfare and employment for sanctioned and non-sanctioned individuals registered either at 
agencies that frequently impose sanctions or at agencies that do not. The means of the variables are measured for the first eight months after the (hypothetical) sanction date ${ }^{15}$

Table 4: Description of outcome variables based on instrument $Z_{1}$

\begin{tabular}{|c|c|c|c|c|c|c|c|c|}
\hline & \multicolumn{4}{|c|}{ Outflow from welfare } & \multicolumn{4}{|c|}{ Employment uptake } \\
\hline & \multicolumn{2}{|c|}{$Z_{1}=0$} & \multicolumn{2}{|c|}{$Z_{1}=1$} & \multicolumn{2}{|c|}{$Z_{1}=0$} & \multicolumn{2}{|c|}{$Z_{1}=1$} \\
\hline & $\mathrm{S}=0$ & $\mathrm{~S}=1$ & $\mathrm{~S}=0$ & $\mathrm{~S}=1$ & $\bar{S}=0$ & $\mathrm{~S}=1$ & $\mathrm{~S}=0$ & $\mathrm{~S}=1$ \\
\hline \multicolumn{9}{|c|}{ Month } \\
\hline 1 & .1343 & .1320 & .1363 & .1317 & .1208 & .0780 & .1231 & .0659 \\
\hline 2 & .1390 & .1400 & .1491 & .1377 & .1298 & .0980 & .1323 & .1198 \\
\hline 3 & .1516 & .1640 & .1589 & .1856 & .1390 & .1180 & . 1363 & .1617 \\
\hline 4 & .1688 & .1840 & .1728 & .2335 & .1525 & .1220 & .1513 & .2096 \\
\hline 5 & .1863 & .2320 & .1973 & .2814 & .1699 & .1300 & .1695 & .2395 \\
\hline 6 & .2036 & .2560 & .2189 & .3293 & .1822 & .1520 & .1841 & .2635 \\
\hline 7 & .2233 & .2680 & .2364 & .3533 & .1903 & .1700 & .2010 & .2754 \\
\hline 8 & .2409 & .2860 & .2554 & .3413 & .1985 & .1860 & .2057 & .2814 \\
\hline
\end{tabular}

Remarks: $\mathrm{S}=0$ denotes non-sanctioned individuals and $\mathrm{S}=1$ denotes sanctioned individuals. $Z_{1}$ refers to the sanction strategy of welfare agencies. $Z_{1}=0$ denotes less strict agencies and $Z_{1}=1$ denotes agencies that frequently apply sanctions.

As can be seen from Table 4 , the share of persons leaving the welfare system and taking up employment increases over time in all subgroups. For example, $13.43 \%$ of the non-sanctioned persons who are registered at agencies that do not frequently impose sanctions have left the welfare system one month after the (hypothetical) sanction date. This share increases steadily and amounts to $24.09 \%$ eight months after the (hypothetical) sanction. For the sanctioned group in the same agencies we observe an increase in the outflow rate from $13.20 \%$ to $28.60 \%$. A similar picture arises with respect to employment uptake. However, the employment rates at the end of the observation period are not as high as the outflow rates from welfare since we only look at employment subject to social insurance contributions ${ }^{16}$ Under this restricted definition, $12.08 \%$ of the non-sanctioned group in less strict agencies take up employment one month after the (hypothetical) sanction, whereas after eight months $19.85 \%$ of the individuals have found a job. For the sanctioned persons in the same agencies, employment probabilities increase from $7.80 \%$ to $18.60 \%$.

Interestingly, we observe a more pronounced increase both in the outflow rate from welfare and in the employment probability for the sanctioned individuals and in particular for the sanctioned persons in agencies that frequently impose sanctions. Within these agencies, $13.17 \%$ of the persons with a benefit cut leave the welfare system one month after the sanction. Eight months after the sanction more than one third of the sanctioned individuals have overcome welfare dependency. Similarly, the employment probability increases from $6.59 \%$ to $28.14 \%$.

\footnotetext{
${ }^{15}$ See Table A.1 in the appendix for the corresponding statistics based on instrument $Z_{2}$. These statistics show a similar pattern to those presented in Table 4 based on $Z_{1}$.

${ }^{16}$ The administrative data that we use to measure our outcome variables do not contain information about spells of marginal employment not subject to social security contributions. Similarly, self-employment is also excluded from the definition. Welfare recipients could also leave the welfare system for other reasons without taking up any kind of employment.
} 
Outflow from benefit receipt and employment rates for sanctioned individuals start at a lower level than the corresponding figures of the non-sanctioned. This might reflect the fact that the sanctioned persons are a selective group that faces disadvantages with respect to labor market participation. As shown in Table 3, for example, the less qualified persons are over-represented among the sanctioned group. However, at the end of our observation period the sanctioned persons do better than the non-sanctioned individuals. The only exception is employment uptake in agencies that do not frequently impose sanctions. Here, employment rates after eight months are a little lower for sanctioned persons than for non-sanctioned persons. Given the large increase in employment rates among the sanctioned individuals, however, this group is likely to catch up and to overtake the group of the non-sanctioned shortly after our observation period ends. Thus, the numbers displayed in Table 4 provide first descriptive evidence for the effectiveness of sanctions.

\subsection{Estimation Results}

Our econometric analysis confirms the descriptive evidence. Before describing the results in detail, we briefly look at the first stage regression results. The first stage regression is identical for each outcome variable (welfare receipt and employment uptake in the first eight months after the (hypothetical) sanction date) and is presented for instrument $Z_{1}$ in the left part of Table 5. As can be seen from the table, our instrument has a significantly positive effect on the sanction probability. Individuals registered at agencies that frequently impose sanctions face a 2.86 percentage point higher probability of getting a sanction than individuals registered at the other agencies. Given the low average sanction rate on average, this is a large effect. The effect is also large in absolute terms when compared to the coefficients of the other covariates included in the model 17

The $F$ statistic for significance of the instrument $Z_{1}$ in the first stage regression is 10.64 . It is thus close to the threshold value of 10 suggested by Staiger and Stock (1997) to indicate a potential weak instrument problem 18 To investigate whether a weak instrument problem is in fact present, we use the second instrument $Z_{2}$ which differentiates between agencies with a sanction rate above and below the median level. In this case, we estimate an even larger

\footnotetext{
${ }^{17}$ With respect to the other covariates we observe that men are more likely to receive benefit cuts than women. Younger individuals (aged 18 to 24) face a higher risk of being sanctioned than do older people. In addition, the less educated are relatively prone to sanctions. Individuals with the lowest educational achievement (secondary general school) have a 1.3 to 2.1 higher sanction probability than persons with an intermediate secondary school degree or a university entrance diploma, respectively. Household size and the number of children do not influence the sanction probability. Disabled persons and persons with care obligations are less likely to receive a benefit cut but the effect is not statistically significant. No differences are found between migrants and German natives. Those individuals who have been employed before UBII receipt are more likely to get a sanction since caseworkers may regard sanctions as effective within this group. Previous spells of unemployment do not matter, nor do the regional variables included in the model have any effect on the sanction probability. Therefore, labor market or economic conditions in the regions do not influence or determine whether a person is sanctioned or not.

${ }^{18} \mathrm{We}$ rely on this rule of thumb since we cannot apply the tests proposed by Stock and Yogo (2005) because we use only one instrument and do not assume homoscedastic errors, but allow for clustering at the agency level.
} 
impact on the individual sanction probability in the first stage regression. As can be seen from the right-hand side of Table 5 the coefficient of the instrument $Z_{2}$ is highly significant and amounts to 4.78 percentage points. The $F$ statistic is 122.09 and thus considerably larger than the threshold value. Therefore, besides giving further insight into the effectiveness of sanctions, $Z_{2}$ also allows us to assess how precisely the sanction effect is estimated using instrument $Z_{1}$.

Table 5: First stage results based on instruments $Z_{1}$ and $Z_{2}$

\begin{tabular}{|c|c|c|}
\hline & $\overline{Z Z_{1}}$ & $\overline{Z_{2}}$ \\
\hline $\bar{Z}$ & $\begin{array}{c}0.0286 \\
(0.0087)\end{array}$ & $\begin{array}{c}0.0478 \\
(0.0043)\end{array}$ \\
\hline \multicolumn{3}{|l|}{ Gender (reference: female) } \\
\hline Male & $\begin{array}{c}0.0177 \\
(0.0051)\end{array}$ & $\begin{array}{c}0.0184 \\
(0.0051)\end{array}$ \\
\hline \multicolumn{3}{|l|}{ Age (reference: 25 to 34 years) } \\
\hline 18 to 24 years & $\begin{array}{c}0.0184 \\
(0.0101))\end{array}$ & $\begin{array}{c}0.0180 \\
(0.0101)\end{array}$ \\
\hline 35 to 44 years & $\begin{array}{l}-0.0171 \\
(0.0084)\end{array}$ & $\begin{array}{l}-0.0172 \\
(0.0085)\end{array}$ \\
\hline 45 to 57 years & $\begin{array}{l}-0.0337 \\
(0.0097)\end{array}$ & $\begin{array}{l}-0.0345 \\
(0.0097)\end{array}$ \\
\hline \multicolumn{3}{|c|}{ Schooling (reference: secondary general school) } \\
\hline Intermediate secondary school & $\begin{array}{c}-0.0131 \\
(0.0053)\end{array}$ & $\begin{array}{c}-0.0116 \\
(0.0053)\end{array}$ \\
\hline University entrance diploma & $\begin{array}{l}-0.0214 \\
(0.0082)\end{array}$ & $\begin{array}{c}-0.0203 \\
(0.0083)\end{array}$ \\
\hline Other or missing & $\begin{array}{c}0.0097 \\
(0.0110)\end{array}$ & $\begin{array}{c}0.0091 \\
(0.0109)\end{array}$ \\
\hline \multicolumn{3}{|c|}{ Migration background (reference: non-migrants) } \\
\hline Migrant & $\begin{array}{c}0.0049 \\
(0.0074)\end{array}$ & $\begin{array}{c}0.0044 \\
(0.0072)\end{array}$ \\
\hline \multicolumn{3}{|c|}{ Household size (reference: 2 Persons) } \\
\hline 1 Person & $\begin{array}{c}0.0090 \\
(0.0067)\end{array}$ & $\begin{array}{c}0.0077 \\
(0.0068)\end{array}$ \\
\hline 3 or more persons & $\begin{array}{l}-0.0046 \\
(0.0063)\end{array}$ & $\begin{array}{l}-0.0046 \\
(0.0062)\end{array}$ \\
\hline \multicolumn{3}{|c|}{ Number of children (reference: 1 child ) } \\
\hline No children & $\begin{array}{c}-0.0010 \\
(0.0069)\end{array}$ & $\begin{array}{c}-0.0018 \\
(0.0069)\end{array}$ \\
\hline 2 or more children & $\begin{array}{l}-0.0050 \\
(0.0072)\end{array}$ & $\begin{array}{l}-0.0070 \\
(0.0071)\end{array}$ \\
\hline \multicolumn{3}{|l|}{ Obstacles to employment } \\
\hline Disabled & $\begin{array}{c}-0.0078 \\
(0.0133)\end{array}$ & $\begin{array}{c}-0.0085 \\
(0.0135)\end{array}$ \\
\hline Care obligation & $\begin{array}{c}-0.0106 \\
(0.0099)\end{array}$ & $\begin{array}{c}-0.0063 \\
(0.0098)\end{array}$ \\
\hline \multicolumn{3}{|c|}{ Status before receipt of welfare benefits } \\
\hline (Minor) employment & $\begin{array}{c}0.0141 \\
(0.0058)\end{array}$ & $\begin{array}{c}0.0136 \\
(0.0058)\end{array}$ \\
\hline \multicolumn{3}{|c|}{ Number of previous unemployment spells (reference: 2 or 3 ) } \\
\hline 0 or 1 & $\begin{array}{c}-0.0014 \\
(0.0047)\end{array}$ & $\begin{array}{l}-0.0007 \\
(0.0046)\end{array}$ \\
\hline 4 or more & $\begin{array}{c}0.0140 \\
(0.0095)\end{array}$ & $\begin{array}{c}0.0139 \\
(0.0095)\end{array}$ \\
\hline Missing & $\begin{array}{c}0.0043 \\
(0.0104)\end{array}$ & $\begin{array}{c}0.0046 \\
(0.0103)\end{array}$ \\
\hline Regional information & & \\
\hline City District & 0.0088 & 0.0110 \\
\hline
\end{tabular}


Table 5: First stage results based on instruments $Z_{1}$ and $Z_{2}$ (continued)

\begin{tabular}{lcc}
\hline \hline & $Z_{1}$ & $Z_{2}$ \\
\hline \hline \multirow{2}{*}{ East Germany } & $(0.0085)$ & $(0.0086)$ \\
& -0.0179 & -0.0043 \\
Unemployment ratio (high) & $(0.0142)$ & $(0.0114)$ \\
& -0.0001 & -0.0023 \\
GDP (high) & $(0.0139)$ & $(0.0105)$ \\
& 0.0025 & -0.0036 \\
Welfare ratio (high) & $(0.0077)$ & $(0.0064)$ \\
& -0.0052 & -0.0041 \\
Current welfare spell & $(0.0074)$ & $(0.0077)$ \\
\hline Months in welfare before 10/2006 & -0.0007 & \\
& $(0.0005)$ & -0.0006 \\
Start after 10/2006 or missing & -0.0229 & -0.0205 \\
& $(0.0103)$ & $(0.0104)$ \\
\hline Constant & 0.0594 & 0.0370 \\
& $(0.0103)$ & $(0.0106)$ \\
\hline Observations & 15361 & 15361 \\
\hline F statistic & 10.64 & 122.09 \\
\hline \hline
\end{tabular}

Remarks: F statistics derive from tests of significance of the instrumental variable $\mathrm{Z}$ in the first stage regressions. $Z_{1}$ refers to the sanction strategy of welfare agencies and $Z_{2}$ refers to the actually observed sanction rates within the agencies.

Based on $Z_{1}$, the upper part of Table 6 provides the estimation results for the effect of a sanction on further welfare receipt in the first eight months after the (hypothetical) benefit cut 19 The negative coefficients of the sanction variable reveal that the outflow from welfare increases due to an imposed sanction even after controlling for a number of individual and regional characteristics. In the first three months the effect is modest and not statistically significant. This probably reflects the fact that even if a sanction induces individuals to search more intensively for employment, it may take some time until they find a job that generates a sufficient income. In the fourth month we observe a large increase in the outflow rate. The effect becomes statistically significant in the fifth month and amounts to 0.743 at the end of the observation period. This figure indicates that a benefit cut increases the probability of leaving the welfare system within eight months after the benefit cut by 74.3 percentage points and thus constitutes a very considerable sanction effect.

The precision of the estimated effects, however, suffers from large standard errors. Therefore, we use instrument $Z_{2}$ to check for robustness. As can be seen from the lower part of Table 6. the results based on this instrument are similar to the results obtained using $Z_{1}$, but are more precisely estimated as reflected by the lower standard errors. Again, we observe a modest

\footnotetext{
${ }^{19}$ In the estimation concerning welfare receipt we define the dependent variable as 1 if an individual is still in the welfare system and receives benefits and as 0 otherwise. Therefore, we estimate the effect of a sanction on the probability of staying dependent on welfare. We could also define the variable the other way round, as was done for convenience in Table 4 to facilitate the comparison of drop-out rates from welfare with employment rates. The definition of the outcome variable does not influence the results. See Table A.2 for the detailed estimation results including all considered covariates.
} 
and insignificant sanction effect in the first three months after the benefit cut, followed by a jump in the outflow rate from welfare in the fourth month. The sanction effect in this month is highly significant. It amounts to 51.56 percentage points and is thus even larger than the effect of 38.2 percentage points measured with instrument $Z_{1}$. In the following months, the effect is statistically significant throughout and shows a similar pattern of development as in the specification with $Z_{1}$. At the end of our observation period the effect amounts to nearly 70 percentage points, which is only a little less than the effect measured on the basis of $Z_{1}$ (74.3 percentage points). Given the similarity between the two estimates, we conclude that our estimation approach does not suffer from a weak instrument problem. The sanction effect is of considerable size.

Table 6: 2SLS estimates on welfare receipt

\begin{tabular}{lcccccccc}
\hline \hline Month & 1 & 2 & 3 & 4 & 5 & 6 & 7 & 8 \\
\hline \hline Sanction & 0.0343 & -0.1312 & -0.0162 & -0.3823 & -0.5624 & -0.7394 & -0.5572 & -0.7433 \\
(based on $\left.Z_{1}\right)$ & $(0.3090)$ & $(0.3013)$ & $(0.3285)$ & $(0.2966)$ & $(0.3339)$ & $(0.3459)$ & $(0.4158)$ & $(0.4305)$ \\
\hline \multicolumn{10}{c}{} & & & & & & & \\
\hline Sanction & -0.2039 & -0.1793 & -0.2992 & -0.5156 & -0.5414 & -0.6227 & -0.7153 & -0.6881 \\
(based on $\left.Z_{2}\right)$ & $(0.2073)$ & $(0.1809)$ & $(0.1832)$ & $(0.1879)$ & $(0.1757)$ & $(0.1790)$ & $(0.2327)$ & $(0.2255)$ \\
\hline \hline Observations & \multicolumn{10}{c}{15361} & & \\
\hline \hline
\end{tabular}

Remarks: The upper part of the table refers to the estimation in which $Z_{1}$ (sanction strategy of welfare agencies) is used as instrument, the lower part of the table refers to the estimation in which $Z_{2}$ (actually observed sanction rates within welfare agencies) is used as instrument. Detailed results for $Z_{1}$ including all covariates are displayed in Table A.2 in the appendix. The detailed results for $Z_{2}$ are very similar and not shown here. They are available upon request.

Table 7 contains the treatment effects if the transition to employment (employment subject to social security contributions) is considered as the dependent variable. For the results in the upper part of the table, instrument $Z_{1}$ was used. We estimate that the probability of finding a job after a sanction is imposed increases by 20 to 25 percentage points at the beginning of our observation period. It then rises to 50 to 60 percentage points from the third to sixth month after the benefit cut and increases further to around 80 percentage points at the end of the period under consideration, when the effect is also statistically significant. Again, this is a fairly strong sanction effect but, unfortunately, the precision of the estimate suffers from high standard errors and the up-and-down movement in the size of the estimated coefficients. Therefore, we look once more at the corresponding results using $Z_{2}$ as instrumental variable (see the lower part of Table 7). Here we observe a similar up-and-down pattern in the size of coefficients. However, while the estimates are larger in magnitude at the beginning of the observation period compared to the estimates based on $Z_{1}$, they are somewhat lower at the end. In the last month of the observation period the effect amounts to about 55 percentage points. The sanction effect is thus still large and highly significant. It states that the probability of a welfare recipient finding a job increases by more than 50 percentage points when the welfare agency decides to increase the sanction rate from below to above the median level. 
The smaller size of the coefficients for the treatment variable in the estimation approach using $Z_{2}$ as instrument is not necessarily due to the reduced variance of the estimates. It may be the case that a tough sanction strategy has an effect per se and induces more outflow from welfare to work than can be measured by just looking at statistical sanction rates within welfare agencies. Thus, the effect of 55 percentage points estimated with $Z_{2}$ might be regarded as a lower bound of the sanction effect on employment. Likewise, the estimated effect of 80 percentage points using $Z_{1}$ might be regarded as an upper bound. Therefore, we conclude that the sanction effect on employment is in a similar range as the effect on welfare receipt, and lies well above 50 percentage points. These figures fit into the existing literature. For example, van den Berg, van der Klaauw, and van Ours (2004) find that the probability of an average 25-year-old Dutch welfare recipient in the city of Rotterdam of leaving the welfare system within two years increases from $66 \%$ to $91 \%$ if a sanction is imposed after 6 months of being on welfare. For a 50 -year-old, the corresponding probability increases from $29 \%$ to $54 \%$.

Table 7: 2SLS estimates on employment

\begin{tabular}{lcccccccc}
\hline \hline Month & 1 & 2 & 3 & 4 & 5 & 6 & 7 & 8 \\
\hline \hline Sanction & 0.2427 & 0.1723 & 0.4337 & 0.5961 & 0.5001 & 0.5790 & 0.8802 & 0.7991 \\
(based on $\left.Z_{1}\right)$ & $(0.3485)$ & $(0.3281)$ & $(0.3584)$ & $(0.3264)$ & $(0.3809)$ & $(0.3602)$ & $(0.3641)$ & $(0.3647)$ \\
\hline \multicolumn{1}{l}{ Sanction } & 0.2880 & 0.2097 & 0.2590 & 0.3678 & 0.3878 & 0.4440 & 0.5595 & 0.5367 \\
(based on $\left.Z_{2}\right)$ & $(0.1613)$ & $(0.1535)$ & $(0.1653)$ & $(0.1525)$ & $(0.1688)$ & $(0.1673)$ & $(0.1771)$ & $(0.1739)$ \\
\hline \hline Observations & \multicolumn{10}{c}{15361} & & &
\end{tabular}

Remarks: The upper part of the table refers to the estimation in which $Z_{1}$ (sanction strategy of welfare agencies) is used as instrument, the lower part of the table refers to the estimation in which $Z_{2}$ (actually observed sanction rates within welfare agencies) is used as instrument. Detailed results for $Z_{1}$ including all covariates are displayed in Table A.3 in the appendix. The detailed results for $Z_{2}$ are very similar and not shown here. They are available upon request.

The influence of the other covariates is as expected but far more modest quantitatively when compared to the sanction effect (see Tables A.2 for welfare receipt and A.3 for employment). Older individuals face a higher risk of remaining in welfare receipt than younger persons. The same is true for less qualified persons. In the last month of the observation period, the individuals with the lowest educational achievement (secondary general school) have a nearly 10 percentage point lower probability of leaving the welfare system than persons with the highest educational achievement (university entrance diploma). Migrants are more likely to stay on benefits than native Germans. Individuals with children are likewise more at risk of remaining in the welfare system. However, for persons living in large households (three or more persons) the probability of terminating welfare benefit receipt is larger than in single households and households with two persons. When care obligations are present, individuals find it harder to leave welfare. Interestingly, the probability of disabled persons leaving the welfare system is larger than for the non-handicapped. Even though the effect is not significant, it may be that caseworkers, after a certain amount of time, relabel some of the disabled as not being capable 
of work anymore and therefore shift this group from UBII to welfare aid, which is a last resort benefit, that does not require labor market participation or participation in welfare-to-work programs. Persons with employment experience immediately before UBII receipt are somewhat more likely to leave the welfare system. Previous spells of unemployment do not matter much. With respect to the regional characteristics considered in the estimation, persons living in urban districts are less likely to leave the welfare system. In addition, persons in regions with a high welfare ratio (as measured at the end of 2003) face more difficulties in overcoming welfare dependency.

The coefficients of the covariates also show the expected signs when uptake of employment (subject to social insurance contribution) is considered as the outcome of interest. Men are more likely to find a job than women. Middle-aged individuals (aged 25 to 44) face better employment prospects than young persons (aged 18 to 24 ) or the elderly (aged 45 to 57). Employment chances also increase with the level of educational attainment. Migrants, disabled people and persons with care obligations have a lower chance of finding a job. Individuals who have been employed prior to UBII receipt are more likely to find a job, perhaps reflecting the fact that recent work experience serves as a signal to employers. The number of previous unemployment spells does not influence employment chances. With respect to the macroeconomic variables included in the model, we find that persons living in regions with a high GDP have relatively good chances of finding a job, whereas employment probabilities are lower in regions with high welfare ratios. However, as in the case of welfare receipt, the effects of individual and regional covariates on employment are quite modest compared to the effect of sanctions.

We recall that the estimated sanction effects have to be interpreted as LATEs. They measure the effect of a sanction on those individuals who are not sanctioned in an agency with a less strict sanction regime, but who will be sanctioned if the agency decides to change its policy and impose sanctions more frequently. Thus, these LATEs can be interpreted as an estimate of the effect of an intensified use of sanctions. Our results show that tightening the sanction policy will be quite effective in reducing welfare dependency and increasing employment uptake ${ }^{20}$

\section{Conclusion}

Recent studies investigating the effect of sanctions imposed on unemployment benefit and welfare benefit recipients show that benefit cuts substantially reduce unemployment and increase employment uptake among the sanctioned persons. However, their empirical basis is limited and it is hard to generalize their findings. First, the existing studies are restricted to small geographic areas and thus may be based on a specific subgroup of benefit recipients. Second,

\footnotetext{
${ }^{20}$ All the results relate to the transition from welfare to work or other employment statuses. Since we do not have information about match quality and job stability and since our observation period ends in December 2007, we are not able to consider the long-term effects of benefit sanctions.
} 
most studies rely on limited individual information. In addition, almost all studies neglect the fact that the imposition of sanctions not only depends on characteristics of the individual but also on the policy of the welfare agency at which an individual is registered and which is in charge of the actual imposition of sanctions.

Our data for German welfare agencies show that benefit sanctions are not imposed uniformly when an individual does not comply with his or her duties during the activation process. Rather, there is substantial discretion at the agency level determining whether a sanction is applied or not. While some agencies frequently impose sanctions, the policy of others is less tough. We use these differences in sanction strategies and rates across 154 welfare agencies in Germany as instrumental variables to estimate the effect of a benefit cut on the rate of terminating welfare receipt and the uptake of employment. Specifically, we estimate the effect of a sanction on those individuals who are not sanctioned by an agency with a cautious sanction policy but who are sanctioned by an agency that imposes sanctions more frequently. This LATE can be interpreted as an estimate of the effectiveness of an intensified or general usage of sanctions since the effect is estimated for those individuals who are not necessarily sanctioned because of a severe non-compliance but simply because of the fact that the punishing agency regards sanctions as an important element of its activation and monitoring regime.

Our results show that the intensified use of sanctions is quite effective in reducing welfare dependency and enhancing employment uptake. A sanction increases the probability of leaving the welfare system within eight months after the benefit cut by about 70 percentage points. Similarly, the probability of taking up a job subject to social insurance contribution rises by more than 50 percentage points. Therefore, we conclude that a more intensive use of benefit cuts by welfare agencies will contribute to making the labor market activation of welfare recipients more effective and will substantially increase the transition rate from welfare to work. 


\section{Appendix}

Table A.1: Description of outcome variables based on instrument $Z_{2}$

\begin{tabular}{|c|c|c|c|c|c|c|c|c|}
\hline & \multicolumn{4}{|c|}{ Outflow from welfare } & \multicolumn{4}{|c|}{ Employment uptake } \\
\hline & \multicolumn{2}{|c|}{$Z_{2}=0$} & \multicolumn{2}{|c|}{$Z_{2}=1$} & \multicolumn{2}{|c|}{$Z_{2}=0$} & \multicolumn{2}{|c|}{$Z_{2}=1$} \\
\hline & $\mathrm{S}=0$ & $\mathrm{~S}=1$ & $\mathrm{~S}=0$ & $\mathrm{~S}=1$ & $\mathrm{~S}=0$ & $\mathrm{~S}=1$ & $\mathrm{~S}=0$ & $\mathrm{~S}=1$ \\
\hline \multicolumn{9}{|c|}{ Month } \\
\hline 1 & .1279 & .1241 & .1410 & .1340 & .1167 & .0657 & .1254 & .0774 \\
\hline 2 & .1335 & .1460 & .1478 & .1377 & .1260 & .0803 & .1343 & .1094 \\
\hline 3 & .1456 & .1606 & .1599 & .1717 & .1334 & .1095 & .1433 & .1340 \\
\hline 4 & .1576 & .1825 & .1808 & .2000 & .1438 & .1168 & .1603 & .1509 \\
\hline 5 & .1734 & .2336 & .2023 & .2472 & .1604 & .1241 & .1787 & .1660 \\
\hline 6 & .1901 & .2482 & .2218 & .2811 & .1723 & .1460 & .1923 & .1887 \\
\hline 7 & .2074 & .2774 & .2430 & .2925 & .1802 & .1752 & .2038 & .2019 \\
\hline 8 & .2250 & .2774 & .2612 & .3057 & .1878 & .1752 & .2111 & .2189 \\
\hline
\end{tabular}

Remarks: $\mathrm{S}=0$ denotes non-sanctioned individuals and $\mathrm{S}=1$ denotes sanctioned individuals. $Z_{2}$ refers to the actually observed sanction rates within welfare agencies. $Z_{2}=0$ denotes welfare agencies with a sanction rate below the median and $Z_{2}=1$ denotes agencies with a sanction rate above the median. 
Table A.2: 2SLS estimates on welfare receipt based on instrument $Z_{1}$

\begin{tabular}{|c|c|c|c|c|c|c|c|c|}
\hline Month & 1 & 2 & 3 & 4 & 5 & 6 & 7 & 8 \\
\hline Sanction & $\begin{array}{c}0.0343 \\
(0.3090)\end{array}$ & $\begin{array}{c}-0.1312 \\
(0.3013)\end{array}$ & $\begin{array}{c}-0.0162 \\
(0.3285)\end{array}$ & $\begin{array}{c}-0.3823 \\
(0.2966)\end{array}$ & $\begin{array}{c}-0.5624 \\
(0.3339)\end{array}$ & $\begin{array}{l}-0.7394 \\
(0.3459)\end{array}$ & $\begin{array}{c}-0.5572 \\
(0.4158)\end{array}$ & $\begin{array}{c}-0.7433 \\
(0.4305)\end{array}$ \\
\hline \multicolumn{9}{|l|}{ Gender (reference: female) } \\
\hline Male & $\begin{array}{c}-0.0167 \\
(0.0096)\end{array}$ & $\begin{array}{c}-0.0141 \\
(0.0100)\end{array}$ & $\begin{array}{c}-0.0029 \\
(0.0097)\end{array}$ & $\begin{array}{c}-0.0002 \\
(0.0096)\end{array}$ & $\begin{array}{c}-0.0038 \\
(0.0101)\end{array}$ & $\begin{array}{c}-0.0008 \\
(0.0108) \\
\end{array}$ & $\begin{array}{c}-0.0116 \\
(0.0118)\end{array}$ & $\begin{array}{c}-0.0038 \\
(0.0120) \\
\end{array}$ \\
\hline \multicolumn{9}{|l|}{ Age (reference: 25 to 34 years) } \\
\hline 18 to 24 years & $\begin{array}{c}-0.0505 \\
(0.0129)\end{array}$ & $\begin{array}{c}-0.0428 \\
(0.0148)\end{array}$ & $\begin{array}{c}-0.0343 \\
(0.0139)\end{array}$ & $\begin{array}{c}-0.0182 \\
(0.0144)\end{array}$ & $\begin{array}{c}-0.0184 \\
(0.0160)\end{array}$ & $\begin{array}{c}-0.0028 \\
(0.0169)\end{array}$ & $\begin{array}{c}-0.0060 \\
(0.0194)\end{array}$ & $\begin{array}{c}-0.0017 \\
(0.0192)\end{array}$ \\
\hline 35 to 44 years & $\begin{array}{c}0.0081 \\
(0.0107)\end{array}$ & $\begin{array}{c}0.0064 \\
(0.0110)\end{array}$ & $\begin{array}{c}0.0144 \\
(0.0118)\end{array}$ & $\begin{array}{c}0.0202 \\
(0.0119)\end{array}$ & $\begin{array}{c}0.0184 \\
(0.0136)\end{array}$ & $\begin{array}{c}0.0147 \\
(0.0146)\end{array}$ & $\begin{array}{c}0.0243 \\
(0.0165)\end{array}$ & $\begin{array}{c}0.0258 \\
(0.0170)\end{array}$ \\
\hline 45 to 57 years & $\begin{array}{c}0.0540 \\
(0.0152) \\
\end{array}$ & $\begin{array}{c}0.0525 \\
(0.0164) \\
\end{array}$ & $\begin{array}{c}0.0665 \\
(0.0169) \\
\end{array}$ & $\begin{array}{c}0.0735 \\
(0.0161) \\
\end{array}$ & $\begin{array}{c}0.0673 \\
(0.0174) \\
\end{array}$ & $\begin{array}{c}0.0717 \\
(0.0184) \\
\end{array}$ & $\begin{array}{c}0.0850 \\
(0.0210) \\
\end{array}$ & $\begin{array}{c}0.0876 \\
(0.0213) \\
\end{array}$ \\
\hline \multicolumn{9}{|c|}{ Schooling (reference: secondary general school) } \\
\hline Intermediate secondary school & $\begin{array}{c}-0.0319 \\
(0.0101)\end{array}$ & $\begin{array}{c}-0.0412 \\
(0.0095)\end{array}$ & $\begin{array}{c}-0.0471 \\
(0.0090)\end{array}$ & $\begin{array}{c}-0.0494 \\
(0.0099)\end{array}$ & $\begin{array}{l}-0.0497 \\
(0.0101)\end{array}$ & $\begin{array}{l}-0.0568 \\
(0.0112)\end{array}$ & $\begin{array}{c}-0.0582 \\
(0.0113)\end{array}$ & $\begin{array}{c}-0.0699 \\
(0.0122)\end{array}$ \\
\hline University entrance diploma & $\begin{array}{c}-0.0475 \\
(0.0135)\end{array}$ & $\begin{array}{l}-0.0562 \\
(0.0126)\end{array}$ & $\begin{array}{c}-0.0709 \\
(0.0148)\end{array}$ & $\begin{array}{l}-0.0696 \\
(0.0148)\end{array}$ & $\begin{array}{c}-0.0746 \\
(0.0157)\end{array}$ & $\begin{array}{c}-0.0802 \\
(0.0150)\end{array}$ & $\begin{array}{c}-0.0889 \\
(0.0159)\end{array}$ & $\begin{array}{c}-0.0986 \\
(0.0169)\end{array}$ \\
\hline Other or missing & $\begin{array}{c}0.0388 \\
(0.0128)\end{array}$ & $\begin{array}{c}0.0366 \\
(0.0125)\end{array}$ & $\begin{array}{c}0.0404 \\
(0.0132)\end{array}$ & $\begin{array}{c}0.0258 \\
(0.0173)\end{array}$ & $\begin{array}{c}0.0299 \\
(0.0168)\end{array}$ & $\begin{array}{c}0.0239 \\
(0.0237)\end{array}$ & $\begin{array}{c}0.0262 \\
(0.0225)\end{array}$ & $\begin{array}{c}0.0275 \\
(0.0243)\end{array}$ \\
\hline \multicolumn{9}{|c|}{ Migration background (reference: non-migrants) } \\
\hline Migrant & $\begin{array}{c}0.0290 \\
(0.0095) \\
\end{array}$ & $\begin{array}{c}0.0347 \\
(0.0101) \\
\end{array}$ & $\begin{array}{c}0.0414 \\
(0.0100) \\
\end{array}$ & $\begin{array}{c}0.0394 \\
(0.0102) \\
\end{array}$ & $\begin{array}{c}0.0424 \\
(0.0112) \\
\end{array}$ & $\begin{array}{c}0.0383 \\
(0.0113) \\
\end{array}$ & $\begin{array}{c}0.0353 \\
(0.0115) \\
\end{array}$ & $\begin{array}{c}0.0366 \\
(0.0126) \\
\end{array}$ \\
\hline \multicolumn{9}{|c|}{ Household size (reference: 2 Persons) } \\
\hline 1 Person & $\begin{array}{c}0.0107 \\
(0.0106)\end{array}$ & $\begin{array}{c}0.0160 \\
(0.0111)\end{array}$ & $\begin{array}{c}0.0075 \\
(0.0107)\end{array}$ & $\begin{array}{c}0.0089 \\
(0.0118)\end{array}$ & $\begin{array}{c}0.0069 \\
(0.0127)\end{array}$ & $\begin{array}{c}0.0106 \\
(0.0137)\end{array}$ & $\begin{array}{l}-0.0044 \\
(0.0127)\end{array}$ & $\begin{array}{l}-0.0023 \\
(0.0135)\end{array}$ \\
\hline 3 or more persons & $\begin{array}{c}-0.0494 \\
(0.0104) \\
\end{array}$ & $\begin{array}{c}-0.0595 \\
(0.0108) \\
\end{array}$ & $\begin{array}{c}-0.0618 \\
(0.0104) \\
\end{array}$ & $\begin{array}{c}-0.0628 \\
(0.0108) \\
\end{array}$ & $\begin{array}{c}-0.0665 \\
(0.0127) \\
\end{array}$ & $\begin{array}{c}-0.0759 \\
(0.0131) \\
\end{array}$ & $\begin{array}{c}-0.0807 \\
(0.0146) \\
\end{array}$ & $\begin{array}{c}-0.0872 \\
(0.0151) \\
\end{array}$ \\
\hline \multicolumn{9}{|c|}{ Number of children (reference: 1 child ) } \\
\hline No children & $\begin{array}{c}-0.0651 \\
(0.0126)\end{array}$ & $\begin{array}{c}-0.0772 \\
(0.0119)\end{array}$ & $\begin{array}{c}-0.0786 \\
(0.0137)\end{array}$ & $\begin{array}{c}-0.0775 \\
(0.0133)\end{array}$ & $\begin{array}{c}-0.0734 \\
(0.0133)\end{array}$ & $\begin{array}{l}-0.0905 \\
(0.0136)\end{array}$ & $\begin{array}{c}-0.0994 \\
(0.0149)\end{array}$ & $\begin{array}{c}-0.1048 \\
(0.0152)\end{array}$ \\
\hline 2 or more children & $\begin{array}{c}0.0360 \\
(0.0120) \\
\end{array}$ & $\begin{array}{c}0.0414 \\
(0.0124) \\
\end{array}$ & $\begin{array}{c}0.0393 \\
(0.0130) \\
\end{array}$ & $\begin{array}{c}0.0441 \\
(0.0134) \\
\end{array}$ & $\begin{array}{c}0.0478 \\
(0.0154) \\
\end{array}$ & $\begin{array}{c}0.0482 \\
(0.0162) \\
\end{array}$ & $\begin{array}{c}0.0347 \\
(0.0162) \\
\end{array}$ & $\begin{array}{c}0.0395 \\
(0.0175) \\
\end{array}$ \\
\hline \multicolumn{9}{|l|}{ Obstacles to employment } \\
\hline Disabled & $\begin{array}{c}-0.0039 \\
(0.0139)\end{array}$ & $\begin{array}{l}-0.0031 \\
(0.0149)\end{array}$ & $\begin{array}{c}-0.0047 \\
(0.0143)\end{array}$ & $\begin{array}{c}-0.0217 \\
(0.0142)\end{array}$ & $\begin{array}{c}-0.0187 \\
(0.0148)\end{array}$ & $\begin{array}{l}-0.0074 \\
(0.0148)\end{array}$ & $\begin{array}{c}0.0005 \\
(0.0161)\end{array}$ & $\begin{array}{c}-0.0054 \\
(0.0170)\end{array}$ \\
\hline Care obligation & $\begin{array}{c}0.0328 \\
(0.0164) \\
\end{array}$ & $\begin{array}{c}0.0215 \\
(0.0180) \\
\end{array}$ & $\begin{array}{c}0.0348 \\
(0.0176) \\
\end{array}$ & $\begin{array}{c}0.0113 \\
(0.0270) \\
\end{array}$ & $\begin{array}{c}0.0233 \\
(0.0236) \\
\end{array}$ & $\begin{array}{c}0.0275 \\
(0.0255) \\
\end{array}$ & $\begin{array}{c}0.0457 \\
(0.0243) \\
\end{array}$ & $\begin{array}{c}0.0431 \\
(0.0251) \\
\end{array}$ \\
\hline \multicolumn{9}{|c|}{ Status before receipt of welfare benefits } \\
\hline (Minor) employment & $\begin{array}{c}-0.0125 \\
(0.0084) \\
\end{array}$ & $\begin{array}{c}-0.0159 \\
(0.0089) \\
\end{array}$ & $\begin{array}{c}-0.0113 \\
(0.0089) \\
\end{array}$ & $\begin{array}{c}-0.0177 \\
(0.0100) \\
\end{array}$ & $\begin{array}{c}-0.0208 \\
(0.0100) \\
\end{array}$ & $\begin{array}{c}-0.0130 \\
(0.0111) \\
\end{array}$ & $\begin{array}{c}-0.0152 \\
(0.0108) \\
\end{array}$ & $\begin{array}{c}-0.0176 \\
(0.0119) \\
\end{array}$ \\
\hline \multicolumn{9}{|c|}{ Number of previous unemployment spells (reference: 2 or 3 ) } \\
\hline 0 or 1 & $\begin{array}{c}0.0267 \\
(0.0085)\end{array}$ & $\begin{array}{c}0.0244 \\
(0.0074)\end{array}$ & $\begin{array}{c}0.0236 \\
(0.0079)\end{array}$ & $\begin{array}{c}0.0157 \\
(0.0093)\end{array}$ & $\begin{array}{c}0.0138 \\
(0.0097)\end{array}$ & $\begin{array}{c}0.0114 \\
(0.0110)\end{array}$ & $\begin{array}{c}0.0042 \\
(0.0112)\end{array}$ & $\begin{array}{c}0.0132 \\
(0.0107)\end{array}$ \\
\hline 4 or more & $\begin{array}{c}0.0129 \\
(0.0112)\end{array}$ & $\begin{array}{c}0.0091 \\
(0.0116)\end{array}$ & $\begin{array}{c}0.0088 \\
(0.0115)\end{array}$ & $\begin{array}{c}-0.0096 \\
(0.0134)\end{array}$ & $\begin{array}{l}-0.0077 \\
(0.0151)\end{array}$ & $\begin{array}{c}-0.0056 \\
(0.0166)\end{array}$ & $\begin{array}{l}-0.0081 \\
(0.0158)\end{array}$ & $\begin{array}{c}0.0105 \\
(0.0159)\end{array}$ \\
\hline Missing & $\begin{array}{c}0.0321 \\
(0.0201)\end{array}$ & $\begin{array}{c}0.0358 \\
(0.0203)\end{array}$ & $\begin{array}{c}0.0307 \\
(0.0178) \\
\end{array}$ & $\begin{array}{c}0.0297 \\
(0.0177)\end{array}$ & $\begin{array}{c}0.0252 \\
(0.0195)\end{array}$ & $\begin{array}{c}0.0374 \\
(0.0234)\end{array}$ & $\begin{array}{c}0.0441 \\
(0.0226)\end{array}$ & $\begin{array}{c}0.0651 \\
(0.0228) \\
\end{array}$ \\
\hline \multicolumn{9}{|l|}{ Regional information } \\
\hline City District & $\begin{array}{c}0.0054 \\
(0.0174)\end{array}$ & $\begin{array}{c}0.0148 \\
(0.0112)\end{array}$ & $\begin{array}{c}0.0141 \\
(0.0111)\end{array}$ & $\begin{array}{c}0.0109 \\
(0.0094)\end{array}$ & $\begin{array}{c}0.0172 \\
(0.0096)\end{array}$ & $\begin{array}{c}0.0252 \\
(0.0125)\end{array}$ & $\begin{array}{c}0.0278 \\
(0.0141)\end{array}$ & $\begin{array}{c}0.0266 \\
(0.0146)\end{array}$ \\
\hline East Germany & $\begin{array}{c}0.0215 \\
(0.0234)\end{array}$ & $\begin{array}{c}0.0200 \\
(0.0244)\end{array}$ & $\begin{array}{c}-0.0000 \\
(0.0253)\end{array}$ & $\begin{array}{c}0.0135 \\
(0.0199)\end{array}$ & $\begin{array}{c}0.0216 \\
(0.0208)\end{array}$ & $\begin{array}{c}0.0331 \\
(0.0256)\end{array}$ & $\begin{array}{c}0.0504 \\
(0.0317)\end{array}$ & $\begin{array}{c}0.0318 \\
(0.0304)\end{array}$ \\
\hline Unemployment ratio (high) & $\begin{array}{c}0.0072 \\
(0.0236)\end{array}$ & $\begin{array}{c}0.0039 \\
(0.0235)\end{array}$ & $\begin{array}{c}0.0303 \\
(0.0242)\end{array}$ & $\begin{array}{c}0.0137 \\
(0.0190)\end{array}$ & $\begin{array}{c}0.0053 \\
(0.0200)\end{array}$ & $\begin{array}{l}-0.0023 \\
(0.0247)\end{array}$ & $\begin{array}{l}-0.0068 \\
(0.0310)\end{array}$ & $\begin{array}{c}0.0140 \\
(0.0295)\end{array}$ \\
\hline GDP (high) & $\begin{array}{c}-0.0149 \\
(0.0126)\end{array}$ & $\begin{array}{c}-0.0171 \\
(0.0101)\end{array}$ & $\begin{array}{c}-0.0170 \\
(0.0101)\end{array}$ & $\begin{array}{c}-0.0148 \\
(0.0100)\end{array}$ & $\begin{array}{c}-0.0154 \\
(0.0092)\end{array}$ & $\begin{array}{c}-0.0164 \\
(0.0100)\end{array}$ & $\begin{array}{c}-0.0115 \\
(0.0121)\end{array}$ & $\begin{array}{c}-0.0076 \\
(0.0125)\end{array}$ \\
\hline Welfare ratio (high) & 0.0409 & 0.0338 & 0.0295 & 0.0372 & 0.0385 & 0.0352 & 0.0388 & 0.0363 \\
\hline
\end{tabular}


Table A.2: 2SLS estimates on welfare receipt based on instrument $Z_{1}$ (continued)

\begin{tabular}{lcccccccc}
\hline \hline Month & 1 & 2 & 3 & 4 & 5 & 6 & 7 & 8 \\
\hline \hline Current welfare spell & $(0.0131)$ & $(0.0100)$ & $(0.0098)$ & $(0.0089)$ & $(0.0090)$ & $(0.0114)$ & $(0.0131)$ & $(0.0135)$ \\
\hline Months in welfare before 10/2006 & 0.0037 & 0.0044 & 0.0059 & 0.0065 & 0.0075 & 0.0073 & 0.0080 & 0.0083 \\
& $(0.0006)$ & $(0.0007)$ & $(0.0007)$ & $(0.0007)$ & $(0.0007)$ & $(0.0008)$ & $(0.0008)$ & $(0.0009)$ \\
Start after 10/2006 or missing & 0.0231 & 0.0503 & 0.0820 & 0.0970 & 0.1069 & 0.0920 & 0.1009 & 0.0909 \\
& $(0.0155)$ & $(0.0157)$ & $(0.0176)$ & $(0.0171)$ & $(0.0176)$ & $(0.0192)$ & $(0.0223)$ & $(0.0229)$ \\
\hline Constant & 0.8373 & 0.8370 & 0.7865 & 0.7783 & 0.7573 & 0.7573 & 0.7291 & 0.7146 \\
& $(0.0274)$ & $(0.0258)$ & $(0.0285)$ & $(0.0274)$ & $(0.0280)$ & $(0.0293)$ & $(0.0331)$ & $(0.0341)$ \\
\hline Observations & 15361 & 15361 & 15361 & 15361 & 15361 & 15361 & 15361 & 15361 \\
\hline
\end{tabular}

Remarks: Estimation is based on instrument $Z_{1}$, which refers to the sanction strategy of welfare agencies. $Z_{1}=$ 0 denotes less strict agencies and $Z_{1}=1$ denotes agencies that frequently apply sanctions. 
Table A.3: 2SLS estimates on employment based on instrument $Z_{1}$

\begin{tabular}{|c|c|c|c|c|c|c|c|c|}
\hline Month & 1 & 2 & 3 & 4 & 5 & 6 & 7 & 8 \\
\hline Sanction & $\begin{array}{c}0.2427 \\
(0.3485)\end{array}$ & $\begin{array}{c}0.1723 \\
(0.3281)\end{array}$ & $\begin{array}{c}0.4337 \\
(0.3584)\end{array}$ & $\begin{array}{c}0.5961 \\
(0.3264)\end{array}$ & $\begin{array}{c}0.5001 \\
(0.3809)\end{array}$ & $\begin{array}{c}0.5790 \\
(0.3602)\end{array}$ & $\begin{array}{c}0.8802 \\
(0.3641)\end{array}$ & $\begin{array}{c}0.7991 \\
(0.3647)\end{array}$ \\
\hline \multicolumn{9}{|l|}{ Gender (reference: female) } \\
\hline Male & $\begin{array}{c}0.0257 \\
(0.0087) \\
\end{array}$ & $\begin{array}{c}0.0320 \\
(0.0094)\end{array}$ & $\begin{array}{c}0.0276 \\
(0.0110)\end{array}$ & $\begin{array}{c}0.0298 \\
(0.0113)\end{array}$ & $\begin{array}{c}0.0452 \\
(0.0122)\end{array}$ & $\begin{array}{c}0.0514 \\
(0.0126)\end{array}$ & $\begin{array}{c}0.0590 \\
(0.0124)\end{array}$ & $\begin{array}{c}0.0562 \\
(0.0126) \\
\end{array}$ \\
\hline \multicolumn{9}{|l|}{ Age (reference: 25 to 34 years) } \\
\hline 18 to 24 years & $\begin{array}{c}-0.0424 \\
(0.0148)\end{array}$ & $\begin{array}{c}-0.0423 \\
(0.0149)\end{array}$ & $\begin{array}{c}-0.0569 \\
(0.0153)\end{array}$ & $\begin{array}{l}-0.0601 \\
(0.0145)\end{array}$ & $\begin{array}{c}-0.0637 \\
(0.0160)\end{array}$ & $\begin{array}{c}-0.0661 \\
(0.0168)\end{array}$ & $\begin{array}{c}-0.0868 \\
(0.0189)\end{array}$ & $\begin{array}{c}-0.0833 \\
(0.0182)\end{array}$ \\
\hline 35 to 44 years & $\begin{array}{c}-0.0099 \\
(0.0111)\end{array}$ & $\begin{array}{c}-0.0155 \\
(0.0106)\end{array}$ & $\begin{array}{l}-0.0125 \\
(0.0109)\end{array}$ & $\begin{array}{l}-0.0132 \\
(0.0120)\end{array}$ & $\begin{array}{l}-0.0094 \\
(0.0144)\end{array}$ & $\begin{array}{l}-0.0045 \\
(0.0156)\end{array}$ & $\begin{array}{c}-0.0065 \\
(0.0170)\end{array}$ & $\begin{array}{c}-0.0026 \\
(0.0161)\end{array}$ \\
\hline 45 to 57 years & $\begin{array}{c}-0.0273 \\
(0.0154) \\
\end{array}$ & $\begin{array}{c}-0.0421 \\
(0.0144) \\
\end{array}$ & $\begin{array}{c}-0.0482 \\
(0.0148) \\
\end{array}$ & $\begin{array}{c}-0.0417 \\
(0.0158) \\
\end{array}$ & $\begin{array}{c}-0.0449 \\
(0.0165) \\
\end{array}$ & $\begin{array}{c}-0.0463 \\
(0.0169) \\
\end{array}$ & $\begin{array}{c}-0.0507 \\
(0.0185) \\
\end{array}$ & $\begin{array}{l}-0.0483 \\
(0.0194) \\
\end{array}$ \\
\hline \multicolumn{9}{|c|}{ Schooling (reference: secondary general school) } \\
\hline Intermediate secondary school & $\begin{array}{c}0.0320 \\
(0.0100)\end{array}$ & $\begin{array}{c}0.0298 \\
(0.0100)\end{array}$ & $\begin{array}{c}0.0358 \\
(0.0103)\end{array}$ & $\begin{array}{c}0.0399 \\
(0.0107)\end{array}$ & $\begin{array}{c}0.0336 \\
(0.0107)\end{array}$ & $\begin{array}{c}0.0283 \\
(0.0119)\end{array}$ & $\begin{array}{c}0.0421 \\
(0.0110)\end{array}$ & $\begin{array}{c}0.0489 \\
(0.0112)\end{array}$ \\
\hline University entrance diploma & $\begin{array}{c}0.0454 \\
(0.0149)\end{array}$ & $\begin{array}{c}0.0406 \\
(0.0161)\end{array}$ & $\begin{array}{c}0.0455 \\
(0.0165)\end{array}$ & $\begin{array}{c}0.0437 \\
(0.0168)\end{array}$ & $\begin{array}{c}0.0381 \\
(0.0167)\end{array}$ & $\begin{array}{c}0.0337 \\
(0.0163)\end{array}$ & $\begin{array}{c}0.0435 \\
(0.0159)\end{array}$ & $\begin{array}{c}0.0538 \\
(0.0158)\end{array}$ \\
\hline Other or missing & $\begin{array}{c}-0.0346 \\
(0.0114)\end{array}$ & $\begin{array}{c}-0.0406 \\
(0.0148)\end{array}$ & $\begin{array}{c}-0.0396 \\
(0.0152)\end{array}$ & $\begin{array}{l}-0.0438 \\
(0.0164)\end{array}$ & $\begin{array}{c}-0.0345 \\
(0.0199)\end{array}$ & $\begin{array}{c}-0.0484 \\
(0.0197)\end{array}$ & $\begin{array}{c}-0.0432 \\
(0.0227)\end{array}$ & $\begin{array}{c}-0.0616 \\
(0.0219)\end{array}$ \\
\hline \multicolumn{9}{|c|}{ Migration background (reference: non-migrants) } \\
\hline Migrant & $\begin{array}{c}-0.0213 \\
(0.0086) \\
\end{array}$ & $\begin{array}{c}-0.0263 \\
(0.0092) \\
\end{array}$ & $\begin{array}{l}-0.0230 \\
(0.0087) \\
\end{array}$ & $\begin{array}{l}-0.0321 \\
(0.0093) \\
\end{array}$ & $\begin{array}{l}-0.0200 \\
(0.0099) \\
\end{array}$ & $\begin{array}{l}-0.0262 \\
(0.0097) \\
\end{array}$ & $\begin{array}{c}-0.0240 \\
(0.0103) \\
\end{array}$ & $\begin{array}{c}-0.0184 \\
(0.0102) \\
\end{array}$ \\
\hline \multicolumn{9}{|c|}{ Household size (reference: 2 Persons) } \\
\hline 1 Person & $\begin{array}{c}-0.0346 \\
(0.0105)\end{array}$ & $\begin{array}{l}-0.0314 \\
(0.0117)\end{array}$ & $\begin{array}{c}-0.0258 \\
(0.0114)\end{array}$ & $\begin{array}{l}-0.0234 \\
(0.0123)\end{array}$ & $\begin{array}{l}-0.0095 \\
(0.0127)\end{array}$ & $\begin{array}{l}-0.0179 \\
(0.0130)\end{array}$ & $\begin{array}{c}-0.0199 \\
(0.0143)\end{array}$ & $\begin{array}{c}-0.0202 \\
(0.0143)\end{array}$ \\
\hline 3 or more persons & $\begin{array}{c}0.0180 \\
(0.0103) \\
\end{array}$ & $\begin{array}{c}0.0202 \\
(0.0114) \\
\end{array}$ & $\begin{array}{c}0.0151 \\
(0.0121) \\
\end{array}$ & $\begin{array}{c}0.0217 \\
(0.0135) \\
\end{array}$ & $\begin{array}{c}0.0095 \\
(0.0127)\end{array}$ & $\begin{array}{c}0.0099 \\
(0.0133) \\
\end{array}$ & $\begin{array}{c}0.0219 \\
(0.0158) \\
\end{array}$ & $\begin{array}{c}0.0201 \\
(0.0153) \\
\end{array}$ \\
\hline \multicolumn{9}{|c|}{ Number of children (reference: 1 child ) } \\
\hline No children & $\begin{array}{c}0.0142 \\
(0.0111)\end{array}$ & $\begin{array}{c}0.0134 \\
(0.0120)\end{array}$ & $\begin{array}{c}0.0133 \\
(0.0129)\end{array}$ & $\begin{array}{c}0.0120 \\
(0.0130)\end{array}$ & $\begin{array}{l}-0.0020 \\
(0.0129)\end{array}$ & $\begin{array}{c}0.0031 \\
(0.0127)\end{array}$ & $\begin{array}{c}0.0137 \\
(0.0156)\end{array}$ & $\begin{array}{c}0.0126 \\
(0.0149)\end{array}$ \\
\hline 2 or more children & $\begin{array}{c}-0.0075 \\
(0.0122) \\
\end{array}$ & $\begin{array}{c}-0.0207 \\
(0.0109) \\
\end{array}$ & $\begin{array}{c}-0.0212 \\
(0.0126) \\
\end{array}$ & $\begin{array}{c}-0.0203 \\
(0.0140) \\
\end{array}$ & $\begin{array}{c}-0.0161 \\
(0.0151) \\
\end{array}$ & $\begin{array}{c}-0.0120 \\
(0.0149) \\
\end{array}$ & $\begin{array}{c}-0.0217 \\
(0.0170) \\
\end{array}$ & $\begin{array}{r}-0.0235 \\
(0.0173) \\
\end{array}$ \\
\hline \multicolumn{9}{|l|}{ Obstacles to employment } \\
\hline Disabled & $\begin{array}{c}-0.0447 \\
(0.0106)\end{array}$ & $\begin{array}{c}-0.0450 \\
(0.0106)\end{array}$ & $\begin{array}{c}-0.0304 \\
(0.0140)\end{array}$ & $\begin{array}{l}-0.0409 \\
(0.0125)\end{array}$ & $\begin{array}{c}-0.0500 \\
(0.0128)\end{array}$ & $\begin{array}{c}-0.0571 \\
(0.0134)\end{array}$ & $\begin{array}{c}-0.0606 \\
(0.0133)\end{array}$ & $\begin{array}{c}-0.0616 \\
(0.0127)\end{array}$ \\
\hline Care obligation & $\begin{array}{c}-0.0694 \\
(0.0118) \\
\end{array}$ & $\begin{array}{c}-0.0573 \\
(0.0222) \\
\end{array}$ & $\begin{array}{c}-0.0486 \\
(0.0232) \\
\end{array}$ & $\begin{array}{c}-0.0536 \\
(0.0265) \\
\end{array}$ & $\begin{array}{c}-0.0636 \\
(0.0265) \\
\end{array}$ & $\begin{array}{c}-0.0621 \\
(0.0274) \\
\end{array}$ & $\begin{array}{c}-0.0656 \\
(0.0276) \\
\end{array}$ & $\begin{array}{c}-0.0707 \\
(0.0276) \\
\end{array}$ \\
\hline \multicolumn{9}{|c|}{ Status before receipt of welfare benefits } \\
\hline (Minor) employment & $\begin{array}{c}0.0451 \\
(0.0080) \\
\end{array}$ & $\begin{array}{c}0.0421 \\
(0.0093) \\
\end{array}$ & $\begin{array}{c}0.0412 \\
(0.0097) \\
\end{array}$ & $\begin{array}{c}0.0349 \\
(0.0094) \\
\end{array}$ & $\begin{array}{c}0.0451 \\
(0.0104)\end{array}$ & $\begin{array}{c}0.0420 \\
(0.0106) \\
\end{array}$ & $\begin{array}{c}0.0441 \\
(0.0117) \\
\end{array}$ & $\begin{array}{c}0.0507 \\
(0.0112) \\
\end{array}$ \\
\hline \multicolumn{9}{|c|}{ Number of previous unemployment spells (reference: 2 or 3 ) } \\
\hline 0 or 1 & $\begin{array}{c}-0.0218 \\
(0.0077)\end{array}$ & $\begin{array}{c}-0.0125 \\
(0.0081)\end{array}$ & $\begin{array}{c}-0.0107 \\
(0.0092)\end{array}$ & $\begin{array}{c}-0.0108 \\
(0.0101)\end{array}$ & $\begin{array}{c}-0.0076 \\
(0.0107)\end{array}$ & $\begin{array}{l}-0.0095 \\
(0.0109)\end{array}$ & $\begin{array}{c}-0.0066 \\
(0.0115)\end{array}$ & $\begin{array}{c}-0.0162 \\
(0.0108)\end{array}$ \\
\hline 4 or more & $\begin{array}{c}0.0028 \\
(0.0118)\end{array}$ & $\begin{array}{c}0.0109 \\
(0.0119)\end{array}$ & $\begin{array}{c}-0.0003 \\
(0.0121)\end{array}$ & $\begin{array}{c}0.0097 \\
(0.0124)\end{array}$ & $\begin{array}{c}0.0135 \\
(0.0134)\end{array}$ & $\begin{array}{c}0.0120 \\
(0.0148)\end{array}$ & $\begin{array}{c}-0.0017 \\
(0.0159)\end{array}$ & $\begin{array}{c}-0.0041 \\
(0.0146)\end{array}$ \\
\hline Missing & $\begin{array}{c}-0.0250 \\
(0.0173)\end{array}$ & $\begin{array}{c}-0.0162 \\
(0.0189)\end{array}$ & $\begin{array}{c}-0.0318 \\
(0.0172)\end{array}$ & $\begin{array}{c}-0.0233 \\
(0.0180)\end{array}$ & $\begin{array}{c}-0.0264 \\
(0.0189)\end{array}$ & $\begin{array}{c}-0.0279 \\
(0.0209)\end{array}$ & $\begin{array}{c}-0.0494 \\
(0.0176)\end{array}$ & $\begin{array}{c}-0.0544 \\
(0.0160) \\
\end{array}$ \\
\hline \multicolumn{9}{|l|}{ Regional information } \\
\hline City District & $\begin{array}{c}-0.0071 \\
(0.0099)\end{array}$ & $\begin{array}{c}-0.0014 \\
(0.0098)\end{array}$ & $\begin{array}{c}-0.0025 \\
(0.0106)\end{array}$ & $\begin{array}{c}-0.0087 \\
(0.0109)\end{array}$ & $\begin{array}{c}-0.0114 \\
(0.0118)\end{array}$ & $\begin{array}{c}-0.0141 \\
(0.0109)\end{array}$ & $\begin{array}{c}-0.0188 \\
(0.0121)\end{array}$ & $\begin{array}{c}-0.0125 \\
(0.0119)\end{array}$ \\
\hline East Germany & $\begin{array}{c}0.0125 \\
(0.0175)\end{array}$ & $\begin{array}{c}0.0202 \\
(0.0198)\end{array}$ & $\begin{array}{c}0.0271 \\
(0.0161)\end{array}$ & $\begin{array}{c}0.0069 \\
(0.0165)\end{array}$ & $\begin{array}{c}-0.0026 \\
(0.0177)\end{array}$ & $\begin{array}{c}-0.0131 \\
(0.0193)\end{array}$ & $\begin{array}{c}-0.0226 \\
(0.0128)\end{array}$ & $\begin{array}{c}-0.0176 \\
(0.0162)\end{array}$ \\
\hline Unemployment ratio (high) & $\begin{array}{c}0.0077 \\
(0.0162)\end{array}$ & $\begin{array}{c}-0.0078 \\
(0.0191)\end{array}$ & $\begin{array}{c}-0.0099 \\
(0.0140)\end{array}$ & $\begin{array}{c}0.0151 \\
(0.0156)\end{array}$ & $\begin{array}{c}0.0280 \\
(0.0159)\end{array}$ & $\begin{array}{c}0.0346 \\
(0.0185)\end{array}$ & $\begin{array}{c}0.0495 \\
(0.0103)\end{array}$ & $\begin{array}{c}0.0390 \\
(0.0138)\end{array}$ \\
\hline GDP (high) & $\begin{array}{c}0.0255 \\
(0.0095)\end{array}$ & $\begin{array}{c}0.0263 \\
(0.0084)\end{array}$ & $\begin{array}{c}0.0296 \\
(0.0095)\end{array}$ & $\begin{array}{c}0.0341 \\
(0.0102)\end{array}$ & $\begin{array}{c}0.0405 \\
(0.0104)\end{array}$ & $\begin{array}{c}0.0437 \\
(0.0106)\end{array}$ & $\begin{array}{c}0.0458 \\
(0.0115)\end{array}$ & $\begin{array}{c}0.0452 \\
(0.0108)\end{array}$ \\
\hline Welfare ratio (high) & -0.0199 & -0.0175 & -0.0214 & -0.0258 & -0.0177 & -0.0150 & -0.0215 & -0.0233 \\
\hline
\end{tabular}


Table A.3: 2SLS estimates on employment based on instrument $Z_{1}$ (continued)

\begin{tabular}{lcccccccc}
\hline \hline Month & 1 & 2 & 3 & 4 & 5 & 6 & 7 & 8 \\
\hline \hline Current welfare spell & $(0.0093)$ & $(0.0095)$ & $(0.0102)$ & $(0.0101)$ & $(0.0114)$ & $(0.0100)$ & $(0.0108)$ & $(0.0104)$ \\
\hline Months in welfare before 10/2006 & -0.0013 & -0.0025 & -0.0032 & -0.0039 & -0.0042 & -0.0047 & -0.0045 & -0.0048 \\
& $(0.0006)$ & $(0.0006)$ & $(0.0006)$ & $(0.0006)$ & $(0.0006)$ & $(0.0006)$ & $(0.0007)$ & $(0.0007)$ \\
Start after 10/2006 or missing & -0.0052 & -0.0386 & -0.0498 & -0.0590 & -0.0484 & -0.0466 & -0.0446 & -0.0399 \\
& $(0.0138)$ & $(0.0146)$ & $(0.0151)$ & $(0.0140)$ & $(0.0148)$ & $(0.0154)$ & $(0.0157)$ & $(0.0158)$ \\
\hline Constant & 0.1197 & 0.1565 & 0.1685 & 0.1817 & 0.1968 & 0.2144 & 0.1971 & 0.2112 \\
& $(0.0267)$ & $(0.0259)$ & $(0.0286)$ & $(0.0267)$ & $(0.0288)$ & $(0.0286)$ & $(0.0312)$ & $(0.0319)$ \\
\hline Observations & 15361 & 15361 & 15361 & 15361 & 15361 & 15361 & 15361 & 15361 \\
\hline
\end{tabular}

Remarks: Estimation is based on instrument $Z_{1}$, which refers to the sanction strategy of welfare agencies. $Z_{1}=$ 0 denotes less strict agencies and $Z_{1}=1$ denotes agencies that frequently apply sanctions. 
Figure A.1: Sampled agencies

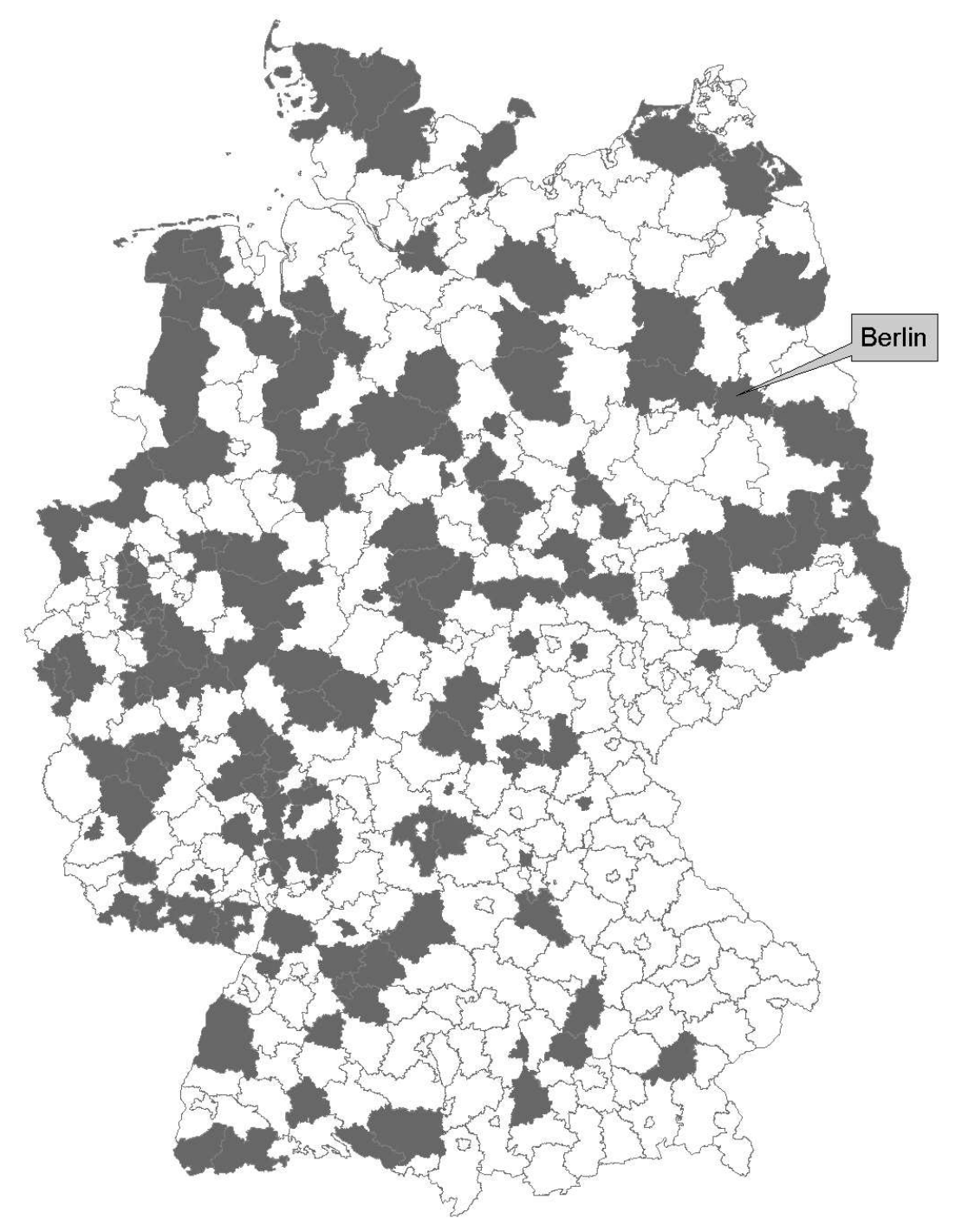


Figure A.2: Sanction strategies

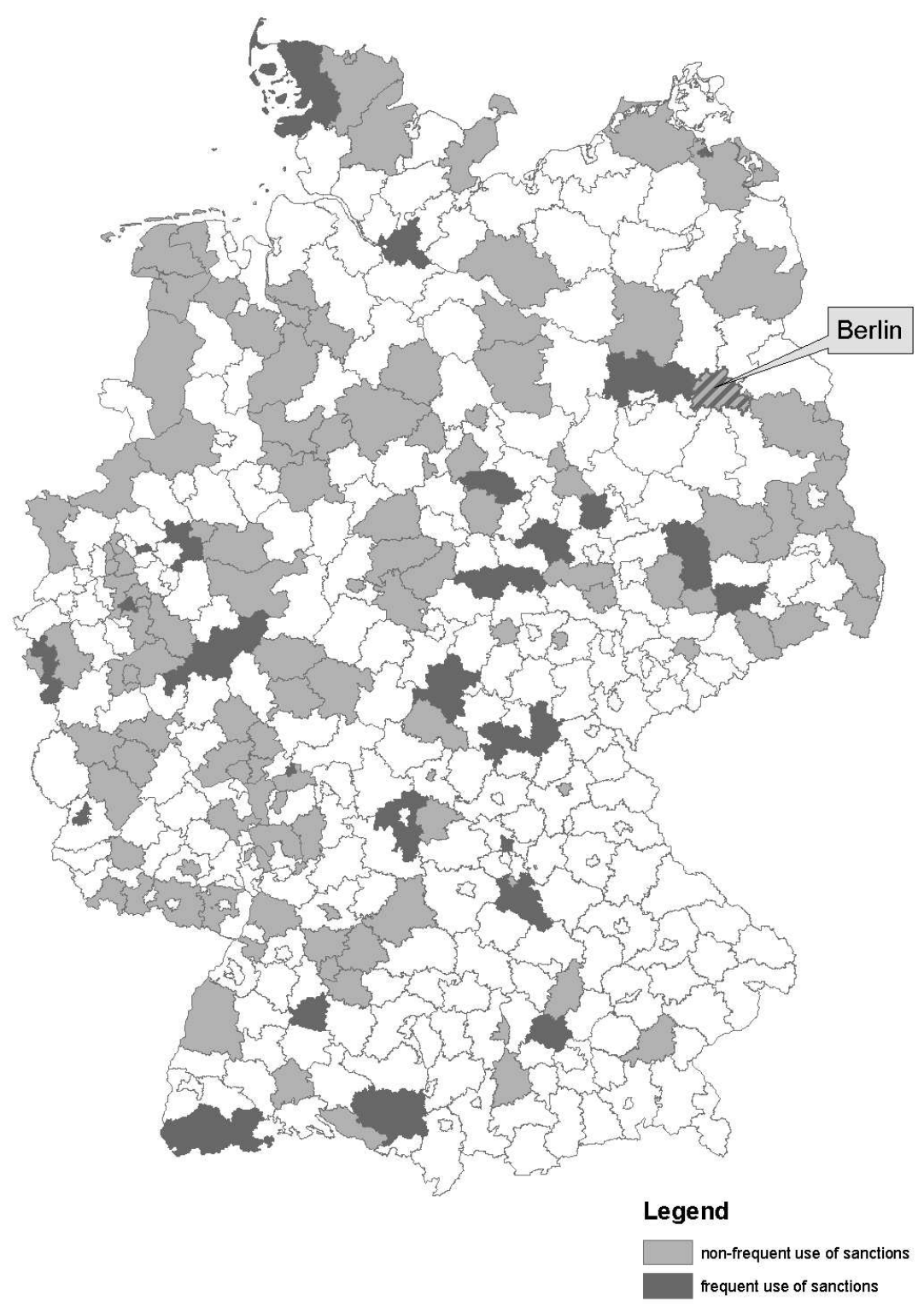


Figure A.3: Sanction rates

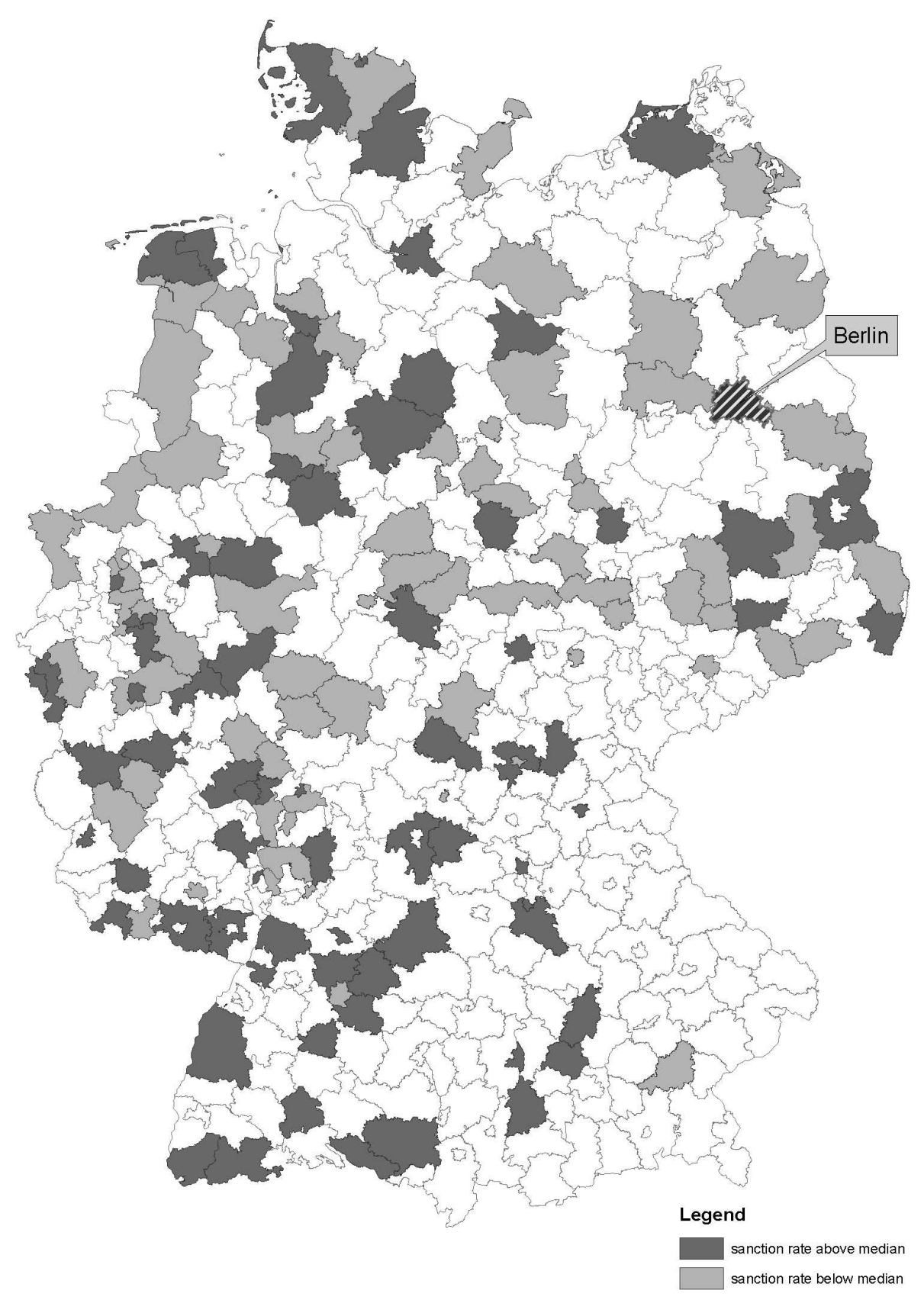




\section{References}

Abbring, J., G. van den Berg, and J. van Ours (2005): "The Effect of Unemployment Insurance Sanctions on the Transistion Rate from Unemployment to Employment," The Economic Journal, 115, 602-630.

Blank, R., and R. Haskins (2001): The New World of Welfare. Brookings Institution Press, Washington, D.C.

Evans, W., and R. Schwab (1995): "Finishing High School and Starting College: Do Catholic Schools Make a Difference?," Quarterly Journal of Economics, 110, 941-974.

Fredriksson, P., And B. Holmlund (2006): "Improving Incentives in Unemployment Insurance: A Review of Recent Research," Journal of Economic Surveys, 20(3), 357-386.

Grogger, J., and L. Karoly (2005): Welfare Reform: Effects of a Decade of Change. Harvard University Press, Cambridge, Massachusetts.

GrubB, M. (2000): "Eligibility Criteria for Unemployment Benefits," OECD Economic Studies, $31(2), 147-184$.

Hofmann, B. (2008): "Work Incentives? Ex-Post Effects of Unemployment Insurance Sanctions - Evidence from West Germany," Iab discussion paper no. 43, IAB Nuremberg.

IAW, AND ZEW (2006): Evaluation der Experimentierklausel nach §6c SGB II. Vergleichende Evaluation des arbeitsmarktpolitischen Erfolgs der Modelle der Aufgabenwahrnehmung "zugelassene kommunale Träger" und "Arbeitsgemeinschaft". Untersuchungsfeld 1: "Deskriptive Analyse und Matching". Jahresbericht 2006. Bundesministerium für Arbeit und Soziales, Berlin.

Imbens, G., And J. AngRist (1994): "Identification and Estimation of Local Average Treatment Effects," Econometrica, 62, 467-475.

Jacobi, L., And J. Kluve (2007): "Before and After the Hartz Reforms. The Performance of Active Labour Market Policy in Germany," Discussion paper 41, RWI Essen.

Lalive, R., J. van Ours, and J. Zweimüller (2005): "The Effect of Benefit Sanctions on the Duration of Unemployment," Journal of the European Economic Association, 3, 1386-1417.

Müller, K.-U., And V. Steiner (2008): "Imposed Benefit Sanctions and the Unemploymentto-Employment Transition - The German Experience," Discussion papers 792, DIW Berlin.

SchneIDER, J. (2008): "The Effect of Unemployment Benefit II Sanctions on Reservation Wages," Discussion paper 19, IAB Nuremberg. 
Staiger, D., And J. Stock (1997): "Instrumental Variables Regression with Weak Instruments," Econometrica, 65, 557-586.

Statistisches Bundesamt (2009): Rechtspflege. Sozialgerichte 200\%. Fachserie 10 Reihe 2.7. Statistisches Bundesamt, Wiesbaden.

Stock, J., And M. Yogo (2005): "Testing for weak instruments in linear IV regression," in Identification and Inference for Econometric Models: Essays in Honor of Thomas Rothenberg, ed. by D. Andrews, and J. Stock, pp. 80-108. Cambridge University Press, Cambridge.

Svarer, M. (2007): "The Effect of Sanctions on the Job Finding Rate: Evidence from Denmark," Discussion paper 3015, IZA Bonn.

van den Berg, G., B. van der Klaauw, and J. van Ours (2004): "Punitive sanctions and the transition rate from welfare to work," Journal of Labor Economics, 22, 211-241.

Wilke, R. (2004): "Eine empirische Analyse von Sanktionen für Arbeitslose in Westdeutschland während der 1980er und 1990er Jahre," Journal for Labour Market Research, 37(1), $45-52$.

ZEW, IAQ, AND TNS EMNID (2008): Evaluation der Experimentierklausel nach §6c SGB II. Vergleichende Evaluation des arbeitsmarktpolitischen Erfolgs der Modelle der Aufgabenwahrnehmung "zugelassene kommunale Träger" und "Arbeitsgemeinschaft". Untersuchungsfeld 3: "Wirkungs- und Effizienzanalyse". Abschlussbericht. Bundesministerium für Arbeit und Soziales, Berlin. 